\title{
Repairing Medical Equipment in Times of Pandemic
}

\author{
Ofer Tur-Sinai \& Leah Chan Grinvald*
}

The COVID-19 pandemic that has gripped the world since early 2020 has underscored the need for an effective right to repair medical equipment. As healthcare systems have been pushed to the limit, keeping critical medical equipment (such as ventilators) in working order has become a matter of life and death. Unfortunately, the ability of hospitals and other healthcare providers to service and fix their medical equipment is often hindered by the tight control that original equipment manufacturers keep over repair of their products. On top of direct contractual restrictions on repair, one of the major difficulties encountered by hospital-based and third-party service providers is the lack of access to service manuals, service keys, schematics, replacement parts, and repair tools. The ability to block access to these critical items is abetted, in large part, by intellectual property laws.

In August 2020, a new federal legislation was introduced to address this problem - the Critical Medical Infrastructure Right-to-Repair Act of 2020 (the "Act"). The Act was designed to facilitate repair of critical medical infrastructure during the current COVID-19 pandemic, and to do so, it addressed various relevant intellectual property issues. Although it failed to pass in 2020, the Act was the first attempt to enact federal repair legislation. Given this, this Article provides a critical analysis of the Act and examines the extent to which it could have served its prescribed goal. In addition, in the event the Act is reintroduced (or similar legislation is introduced) in the coming years, we provide constructive suggestions to improve it. We also investigate the role that courts could play, alongside such legislation, by using policy levers that already exist in intellectual

* Ofer Tur-Sinai, Associate Professor of Law, Ono Academic College (Israel), Visiting Professor, Hebrew University; Leah Chan Grinvald, Associate Dean for Academic Affairs \& Professor of Law, Suffolk University Law School. For helpful comments, suggestions, and discussions, the authors are grateful to Dana Beldiman, Jorge Contreras, Paul Gugliuzza, Eric Johnson, Dmitry Karshtedt, Jason Rantanen, Joshua Sarnoff, Dalindyebo Shabalala as well as the participants of the Works-in-Progress Intellectual Property Colloquium (WIPIP) (Texas A\&M, 2021). For excellent research assistance, the authors thank Nitzan Algaui and Gal David. Deep appreciation is also expressed to the editors of this journal for their thoughtful review and dedicated editorial efforts. 
property law to provide relief to hospital-based and independent service technicians and to mandate manufacturers to cooperate with them in certain circumstances.

I. INTRODUCTION 462

II. JUSTIFICATIONS FOR A RIGHT TO REPAIR MEDICAL EQUIPMENT 466

III. REPAIR RESTRICTIONS 474

IV. THE PROPOSED FEDERAL LEGISLATION 482

A. Suspending IP and Contractual Restrictions ........................... 483

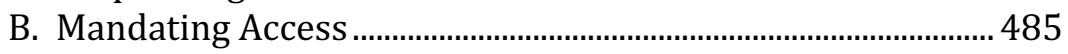

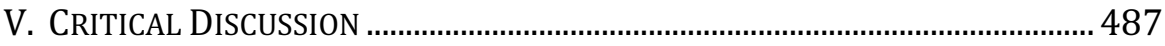

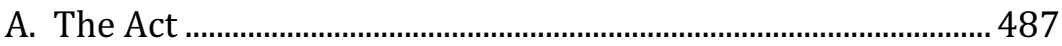

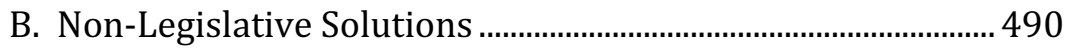

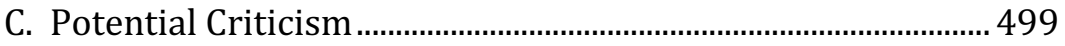

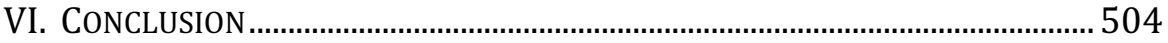

\section{INTRODUCTION}

The COVID-19 global pandemic declared in March $2020^{1}$ has spotlighted the lack of a right to repair medical equipment. More than a year and a half into the pandemic, the global death toll has already surged past 4.9 million individuals at the date of this publication. ${ }^{2}$ As medical teams around the world continue to scramble to treat and provide emergency care for a rising flood of patients, ${ }^{3}$ life-saving medical equipment is being utilized on a scale likely never seen before. The ability to keep critical equipment, such as ventilators, in good working order can mean the life or death of a severely ill patient. ${ }^{4}$

1 Helen Branswell \& Andrew Joseph, WHO Declares the Coronavirus Outbreak a Pandemic, STAT NEws (Mar. 11, 2020), https://www.statnews.com/2020/03/11/whodeclares-the-coronavirus-outbreak-a-pandemic/.

2 WHO Coronavirus (Covid-19) Dashboard, Overview, https://covid19.who.int/ (as of Oct. 24, 2021, citing 4,953,246 global deaths reported to WHO).

3 See Tobias Jones, After a Year of Death and Solitude, Italy is a Sober, Serious Place, GuARDiAn (Feb. 21, 2021, 1:15 AM), https://www.theguardian.com/world/2021/feb/ 21/after-a-year-of-death-and-solitude-italy-is-a-sober-serious-place (recounting the outbreak in Italy in March 2020); John McCormick, When Covid-19 Hit, Mayo Clinic Had to Rethink Its Technology, WALL ST. J. (Feb. 21, 2021), https://www.wsj.com/articles/ when-covid-19-hit-mayo-clinic-had-to-rethink-its-technology-11613937600?mod=hp jr_pos1 (interviewing Cris Ross, Mayo Clinic's CIO, on the rapid changes the Mayo Clinic needed to make to handle the COVID-19 pandemic).

4 See Nathan Proctor, "Life and Death"-Medical Equipment Repairers Push for Right to Repair During COVID-19 Pandemic, U.S. PIRG (May 19, 2020), https://uspirg.org/ 
Although many hospitals and other healthcare facilities (such as hospices or clinics) employ qualified biomedical equipment technicians ${ }^{5}$ (often referred to as "biomeds"), ${ }^{6}$ who are capable of servicing, diagnosing, and even repairing such equipment-they are often not able to do so. ${ }^{7}$ Hospitals are also very limited in their ability to utilize third-party service providers for maintenance and repair. The reason for this is that original equipment manufacturers ("OEMs") have been enforcing strict control over the ability to repair the devices they produce. OEMs use various means to affect this control, including contractual limitations with purchasers or lessees of their devices; restricted access to training and to repair information, parts and tools; technological protection measures on software embedded in the devices; and enforcement of intellectual property protection over various aspects related thereto. ${ }^{8}$

Since the outbreak of COVID-19, hundreds of biomedical engineers across the United States have urged OEMs to provide greater access to what they need to diagnose, maintain, and repair medical equipment for patient care-mostly to no avail. ${ }^{9}$ To keep equipment working, some repair professionals have resorted to self-help measures, such as making or printing replacement parts, and sharing repair manuals and

blogs/covid-19/usp/\%E2\%80\%9Clife-and-death\%E2\%80\%9D-medical-equipmentrepairers-push-right-repair-during-covid-19 (quoting Nader Hammoud, a biomedical engineer, "if 'you don't get that device up and running in an hour or two hours, that patient will die"').

5 See Biomedical Equipment Technician, HealthCarePathway.com, https://www. healthcarepathway.com/health-care-careers/biomedical-technician/ (last visited Feb. 27, 2021); Biomedical Equipment Technician Job Description, GLASSDoor, https:// www.glassdoor.com/Job-Descriptions/Biomedical-Equipment-Technician.htm (last visited Feb. 27, 2021).

6 See, e.g., Nick Staat, iFixit Launches Massive Repair Database For Ventilators and Other Medical Devices, VERGE (May 19, 2020), https://www.theverge.com/2020/5/19/ 21263762/ifixit-medical-device-repair-database-launch.

7 See Jason Koebler, Hospitals Need to Repair Ventilators. Manufacturers Are Making That Impossible, VICE (Mar. 18, 2020, 10:15 AM), https://www.vice.com/en/article/wxekgx/hospitals-need-to-repair-ventilators-manufacturers-are-making-that-impossible (quoting Gay Gordon Bryne, Executive Director of Repair.org, "[e]ven hospital employed biomedical technicians with the best training and qualifications aren't fixing things anymore, they're becoming shipping clerks packaging things to be sent away for repair").

8 See infra Part III.

9 See News Release, Hospital Repair Professionals: Just Let Us Fix Life-Saving Devices Including Ventilators, U.S. PIRG (May 18, 2020), https://uspirg.org/news/usp/hospitalrepair-professionals-just-let-us-fix-life-saving-devices-including-ventilators (relating that 326 biomedical professionals signed a letter to Congress that called for access to repair information). 
software passwords "under the table," among others. ${ }^{10}$ Yet, such measures are not always effective, and they could prompt cease-anddesist letters and lawsuits by OEMs, based on contract and intellectual property law. ${ }^{11}$

Indeed, repair as a general matter and more particularly, measures taken to access repair information, parts, and tools, may implicate various intellectual property issues. ${ }^{12}$ Over the years, patents (both utility and design), trademarks, copyrights, and trade secrets have all been utilized to keep repair within OEMs' control.13 As we have maintained in a previous paper, it is impossible to implement an effective right to repair without addressing intellectual property law. ${ }^{14}$

Policy makers have recently recognized this necessity: in August 2020, a new federal legislation was introduced-the Critical Medical Infrastructure Right-to-Repair Act of 2020 (the "Act"). ${ }^{15}$ Unfortunately, the Act was not passed before the $116^{\text {th }}$ Congressional session ended, and in fact, never made it out of the committee.16 But, as the COVID-19 pandemic is still raging, the need for such legislation has remained acute, and the Act may be re-introduced (or similar legislation introduced) in the current session. ${ }^{17}$

Notably, this is the first time that Congress attempted to take action to facilitate repair of critical medical infrastructure by independent

10 See Glynn Moody, Volunteers 3D-Print Unobtainable \$11,000 Valve for $\$ 1$ To Keep Covid-19 Patients Alive; Original Manufacturer Threatens To Sue, TECHDIRT (Mar. 17, 2020, 1:35 PM) https://www.techdirt.com/articles/20200317/04381644114/volunteers-3d-print-unobtainable-11000-valve-1-to-keep-covid-19-patients-alive-originalmanufacturer-threatens-to-sue.shtml (reporting on Italian volunteers who printed a valve on a 3D printer to fix a ventilator; notably, in an update to the report, it appears that the manufacturer did not threaten to sue).

11 See Kit Walsh, Medical Device Repair Again Threatened With Copyright Claims, ElEc. Frontier Found. (June 11, 2020), https://www.eff.org/deeplinks/2020/06/medical-device-repair-again-threatened-copyright-claims.

12 See Leah Chan Grinvald \& Ofer Tur-Sinai, Intellectual Property Law and the Right to Repair, 88 FoRDHAM L. REv. 63 (2019) (discussing and analyzing intellectual property laws ramifications for repair).

13 See id. at 97-123.

14 Id.

15 Critical Medical Infrastructure Right-to-Repair Act of 2020, H.R. 7956, 116th Cong. (2020); Critical Medical Infrastructure Right-to-Repair Act of 2020, S. 4473, 116th Cong. (2020) [hereinafter the Act].

16 See S. 4473 (116 ${ }^{\text {th }}$ ): Critical Medical Infrastructure Right-to-Repair Act of 2020, GovTRACK, https://www.govtrack.us/congress/bills/116/s4473 (last visited Feb. 27, 2021).

17 Although the "Fair Repair Act," a national repair bill, was introduced to Congress on June 17, 2021, it specifically excludes medical equipment. Fair Repair Act, H.R. 4006, 117th Cong. § 4(5) (2021), https://www.congress.gov/bill/117th-congress/house-bill/ 4006/text. 
service providers. ${ }^{18}$ And, further, to do so, it attempted to address many of the pertinent intellectual property issues implicated by repair. ${ }^{19}$ Given this, a critical analysis of the Act is warranted. This Article provides such an analysis and examines the extent to which the Act could have served (or could serve, if it is re-introduced) its prescribed goal. We question, among other things, the strategy that seems to be reflected in the Act, that is, of providing a temporary relief to the current emergency, rather than amending intellectual property law in a manner that would ensure its preparedness to similar future events. ${ }^{20} \mathrm{We}$ also look into the role that courts could play in the interim (or if enacted, alongside the Act), by using policy levers that exist in intellectual property law to support a right to repair.

The remainder of this Article proceeds in four parts. Part II provides a brief overview of the justifications for a right to repair, with a focus on the medical equipment field. Many of the same justifications are used to support a general right to repair all electronic equipment, but as will be discussed in Part II, there are health-related justifications that underscore the need for a right to repair in this area. Part III will provide an analysis of the current restrictions that hospitals and healthcare facilities face when attempting to repair their medical

18 See infra note 154. The term "independent service providers" refers to those biomedical equipment technicians who service medical equipment but who are not employed as part of OEMs' authorized network of technicians. These independent service providers can be employed by hospitals as full-time employees, or as contractors, as well as by other healthcare facilities, such as hospices, private medical practices, or clinics.

19 See Press Release, Wyden and Clarke Introduce Bill to Eliminate Barriers to Fixing Critical Medical Equipment During the Pandemic, (Aug. 6, 2020) [hereinafter Wyden and Clarke], https://www.wyden.senate.gov/news/press-releases/wyden-and-clarke-introduce-bill-to-eliminate-barriers-to-fixing-critical-medical-equipment-during-thepandemic- (limiting copyright and patent rights to allow for repair).

20 See Ana Santos Rutschman, IP Preparedness for Outbreak Diseases, 65 UCLA L. REV. 1200, 1200 (2018) (arguing that intellectual property laws hinder vaccine development and advocating for "IP Preparedness" to better handle infectious disease outbreaks); Yaniv Heled, Ana Santos Rustchman \& Liza Vertinsky, The Need for the Tort Law Necessity Defense in Intellectual Property Law, U. CHI. L.F. (forthcoming, 2021), https://papers.ssrn.com/sol3/papers.cfm?abstract_id=3642833 (advocating the adoption of a necessity doctrine in IP law and highlighting its potential to play an important role in increasing preparedness ahead of future outbreaks of infectious diseases and other public health emergencies); see also Joshua D. Sarnoff, COVID-19 Highlights Need for Rights to Repair and Produce in Emergencies, Bill of Health Blog (May 19, 2020), https://blog.petrieflom.law.harvard.edu/2020/05/19/covid19-intellectual-propertypatent-law/ (advocating for legislation to adopt automatic, limited exceptions to intellectual property rights during public health emergencies); Jorge L. Contreras, Research and Repair: Expanding Exceptions to Patent Infringement in Response to a Pandemic, $7 \mathrm{~J}$. L. \& BIOSCIENCES 1 (2020) (advocating for exceptions to patent infringement during times of pandemic). 
equipment on their own or through independent service providers. Whether their equipment is leased or owned, these healthcare facilities face a myriad of restrictions in attempting to repair their equipment during the best of times. ${ }^{21}$ During the COVID-19 pandemic, the impact of these restrictions has been amplified. Next, Part IV will turn to the proposed Act and describe the major provisions that would have allowed healthcare facilities the ability to have their own biomeds or third parties service and repair their equipment. Finally, in Part V, we provide a critical analysis of the Act in the hopes that the constructive suggestions can improve it for a future introduction and hopeful enactment. Part $\mathrm{V}$ also discusses certain non-legislative measures that could be used to advance a right to repair medical equipment. In addition, Part $V$ addresses a few counter arguments that could be made against this Article's thesis. We then briefly conclude.

\section{JUSTIFICATIONS FOR A RIGHT TO REPAIR MEDICAL EQUIPMENT}

Before zooming in on medical equipment, a few general words about the right to repair are in order. In recent years, a social movement demanding a right to repair has sprung up in the United States. ${ }^{22}$ The movement, spearheaded by the Repair Association, has focused its efforts primarily on state-level, consumer protection legislation that, if enacted, would require manufacturers of consumer electronics to enable consumers and independent repair shops to repair such products. $^{23}$ The scope of the proposed legislation is intended to be broad, and in most states it encompasses "any product that depends for its functioning, in whole or in part, on digital electronics embedded in or

21 Notably, even where the device is "owned," the software needed to run the device is likely licensed to the "owner," thus undermining their ownership. See generally JASON Schultz \& Aaron Perzanowski, The End of Ownership: Personal Property in the Digital EсоNomy (2018) (exposing that, due to licensing restrictions contained in device software, there is no real "ownership" over purchased devices).

22 See Grinvald \& Tur-Sinai, supra note 12, at 71-81 (discussing the social movement and its emphasis on consumer protection legislation). There is a similar, parallel movement more globally, particularly in the European Union and Australia. See, e.g., Leanne Wiseman \& Kanchana Kariyawasam, US and EU Laws Show Australia's Right to Repair Moment is Well Overdue, Conversation (Feb. 2, 2020, 1:54 PM), https://theconversation.com/us-and-eu-laws-show-australias-right-to-repair-moment-is-well-overdue-127323; Roger Harrabin, EU Brings in 'Right to Repair' Rules for Appliances, BBC NEws (Oct. 1, 2019), https://www.bbc.com/news/business-49884827.

23 For a critical analysis of these efforts, see Grinvald \& Tur-Sinai, supra note 12, at 71-73. So far, over twenty-five states have introduced some form of repair legislation, although no state has yet passed it. See Nathan Proctor, Half of U.S. States Looking to Give Americans the Right to Repair, U.S. PIRG (Mar. 10, 2021), https://uspirg.org/blogs/blog/ usp/half-us-states-looking-give-americans-right-repair. 
attached to the product."24 This definition includes many types of products that we use in our daily lives. ${ }^{25}$ While not the focus of such legislative efforts, medical equipment may be covered by such legislation in some states. ${ }^{26}$ A separate piece of legislation passed (and recently updated) in the state of Massachusetts deals with repairs in the car industry. ${ }^{27}$

The term "right to repair" typically refers to the right of consumers themselves to engage in repair of their own products. In addition, it often encompasses the right of other parties to engage in repairs in a manner that enables consumers to choose who they want to service their products. ${ }^{28}$ While the nature of the consumers' or other parties' legal entitlement in connection with repair under existing or proposed legislation is not necessarily structured as a "right" in the strict legal sense, the term "right to repair" has gained traction among policy makers, advocates and scholars alike. ${ }^{29}$

24 Model State Right-to-Repair Law, RePAIR Ass’n §2, https://repair.org/s/Right-torepair-model-state-law-updated-1-22-20.docx (Jan. 22, 2020) (definition of "digital electronic equipment"). This definition is taken from the model act drafted by the Repair Association as part of its lobbying of state legislatures to enact repair laws. Most of the proposals introduced so far in different states-including, for example, North Carolina, Missouri, Kansas, Iowa, Minnesota \& Illinois-have not significantly deviated from the model act in their scope.

25 Grinvald \& Tur-Sinai, supra note 12, at 77.

26 See Model State Right-to-Repair Law, supra note 24 (providing examples of states that follow the model act in this respect). In some states, the proposed legislation includes some specific language addressing the context of medical devices, while others exempt medical equipment from coverage. For instance, the repair legislation introduced in Hawaii includes a provision that states that nothing shall require a manufacturer of a medical device to comply with any provision in the act that conflicts with the FDA Act. See H.B. 226, 31st Leg., Reg. Sess. § 8 (Haw. 2021). In Massachusetts, the proposed law would exclude from its scope "a class III medical device as established by 21 U.S.C. Section 360c". See H.B. 143, 190th Gen. Court § 1 (Mass. 2017). Finally, in California, while the general repair legislation introduced in 2018 would not apply at all with respect to medical devices (Assemb. B. 2110, 2017-2018 Leg., Reg. Sess. § 42488.4(d)(1) (Cal. 2018)), another bill has been recently introduced that would provide for a separate right to repair medical devices. See S.B. 605, 2021 Leg., Reg. Sess. (Cal. 2021).

27 See Mass. Gen. Laws Ann., ch. 93K (2019). This legislation was recently updated to better address the growing use of telematics in vehicle diagnostics and repair. See An Act to Enhance, Update and Protect the 2013 Motor Vehicle Right to Repair Law and Consumer Rights, H.B. 340, 191st Gen. Court (Mass. 2019-2020). For an analysis of this legislation, see Leah Chan Grinvald \& Ofer Tur-Sinai, Smart Cars, Telematics and Repair, 54 U. Mich. J.L. Reform 283, 294-95, 310-14 (2021).

28 Grinvald \& Tur-Sinai, supra note 12, at 99-100.

29 See Wesley Newcomb Hohfeld, Some Fundamental Legal Conceptions as Applied in Judicial Reasoning, 23 YALE L.J. 16, 30 (1913); Wesley Newcomb Hohfeld, Fundamental Legal Conceptions as Applied in Judicial Reasoning, 26 YALE L.J. 710, 725 (1917). For discussion, see Grinvald \& Tur-Sinai, supra note 12, at 99-100. 
Over the last few years, various justifications have been offered in support of a right to repair consumer products. One prominent justification proposed focuses on the need to preserve consumers' sense of autonomy. ${ }^{30}$ This justification is often intertwined with a perception that a consumer should have the right to repair (or choose where to repair) their stuff because they own it. ${ }^{31}$ This justification is premised on the quid pro quo understanding of a personal property transaction: a consumer pays money for a product, and in return they obtain ownership of that product. ${ }^{32}$ These two interrelated rationales arguably have less relevance with respect to medical equipment used in hospitals or other healthcare facilities. But they may still be widely applicable to personal health equipment, including wearable and implantable devices.

Another justification that is often made for a right to repair is the need to maintain competition in the markets for repair services, replacement parts, and diagnostic tools. ${ }^{33}$ Upholding these markets is not only essential to the businesses that operate in them but is also of great importance for consumers. Absent competition, manufacturers can set prices that have no relation to the value of the services. This argument is particularly strong with respect to vehicles, where an entire industry evolved around independent repair shops. ${ }^{34}$ While the market for third-party entities that repair and service medical equipment is likely less robust, preserving the freedom to compete with manufacturers of medical equipment in the repair market is no less important than in the automotive industry. Whereas, with respect to vehicles, it is likely that many drivers are not able to repair their own cars, the same is not true in the medical equipment realm. Many hospitals and healthcare facilities have their own teams of biomedical technicians on-site, who are trained to provide service and fix medical

30 For a general discussion of arguments rooted in consumer autonomy justifying a right to repair, see Grinvald \& Tur-Sinai, supra note 12, at 67, 81, 89.

31 See Adam Wernick, The 'Right to Repair' Movement Wants You to be Able to Fix Your Own Stuff, The World: Living EarTh (Dec. 24, 2018, 11:30 AM), https:// www.pri.org/stories/2018-12-24/right-repair-movement-wants-you-be-able-fixyour-own-stuff.

32 This is certainly how the U.S. Supreme Court views a straightforward sale transaction, stating in the patent context, "[a] sale transfers the right to use, sell, or import because those are the rights that come along with ownership." Impression Prods., Inc. v. Lexmark Int'l, Inc., 137 S. Ct. 1523, 1534 (2017). See also Aaron Perzanowski, Consumer Perceptions of the Right to Repair, 96 IND. L.J. 361, 383 (2021) (quoting one consumer participant in the article's survey: "I don't think [manufacturers] have any right to tell me what I can do with it after I purchase it.") (alteration in original).

33 Grinvald \& Tur-Sinai, supra note 27, at 291.

34 Id. at 295-98. 
equipment. ${ }^{35}$ As such, enabling on-site repairs can result in a significant decrease of costs for the healthcare industry (not to mention the increased ability to care for patients, which we will address in further detail below). ${ }^{36}$

The ability to decrease healthcare costs is a significant benefit that should not be underestimated to support a right to repair, particularly in the United States, where healthcare costs have skyrocketed in recent years. ${ }^{37}$ During the COVID-19 pandemic, these high costs have likely led to deaths, as Americans who have little or no health insurance have shied away from going to emergency rooms for fear of exorbitant costs. ${ }^{38}$ Although there are programs to help the uninsured with emergency healthcare, they are often unaware of them, or they can still be billed erroneously. ${ }^{39}$ For example, one California couple received a bill for over one million dollars for their COVID hospital treatment.40 And even though the actual amount they needed to pay was approximately forty-two thousand dollars, they still did not have the funds to pay the bill. ${ }^{41}$ Therefore, the ability to reduce healthcare costs due to repair should not be overlooked.

Another justification for a right to repair is rooted in dynamic efficiency considerations. "Where repair markets are open, consumers, independent repair shops, and tool developers have the ability and

35 See infra notes 222-230 and accompanying text.

36 See, e.g., Nathan Proctor \& Kevin O’Reilly, Hospital Repair RestrictionsManufacturer-Imposed Barriers to Fixing Medical Equipment Cause InefFiciencies and DELAYS, U.S. PIRG EDUC. Fund (2020) [hereinafter PIRG REPORT], https://uspirg.org/sites/ pirg/files/reports/Hospital_Repair_Restrictions_USPEF_7.8.20b.pdf (citing Barbara Maguire, "who manages repair and maintenance for more than 80,000 devices across multiple Pennsylvania hospitals," to the effect that having well-trained people on-site lowers costs); Isaac Scher, Hospitals Need Ventilators to Keep Severe COVID-19 Patients Alive, Bus. Insider (June 3, 2020), https://www.businessinsider.com/ventilatormanufacturers-dont-let-hospitals-fix-coronavirus-right-to-repair-2020-5 (discussing the prohibitive training costs imposed by manufacturers).

37 See Why Are Americans Paying More for Healthcare?, Peter G. Peterson Found. (Apr. 20, 2020), https://www.pgpf.org/blog/2020/04/why-are-americans-payingmore-for-healthcare (citing the rise in service costs as a factor in the overall rise of healthcare spending).

38 See Blake Farmer, Hospital Bills for Uninsured COVID-19 Patients Are Covered, But No One Tells Them, NPR (Oct. 22, 2020, 5:00 AM), https://www.npr.org/sections/health-shots/2020/10/22/925942412/hospital-bills-for-uninsured-covid-19patients-are-covered-but-no-one-tells-them (reporting on the death of a Kentucky man who did not make a third trip to the hospital due to his worry over costs).

39 See id. (reporting that the widow received a bill from the hospital, which the hospital later admitted was in error).

40 See Maria L. La Ganga, Her COVID-19 Treatment Cost More than \$1 Million. Who's Going to Pay for It?, L.A. Times (Feb. 8, 2021, 5:00 AM), https://www.latimes.com/california/story/2021-02-08/covid-treatment-hospital-bills-health-insurance-waivers.

41 See id. 
motivation to create new methods of repair, develop ... diagnostic and repair tools, and create user-generated tips, manuals, and kits that could significantly benefit others." 42 This justification seems to be applicable in the context of medical equipment, where user innovation takes place quite often. 43

While servicing and repairing equipment, trained biomedical technicians could generate valuable innovation. More generally, engaging in repair requires and incentivizes observation and acquisition of knowledge. ${ }^{44}$ This is valuable as a general matter. In the context of biomedical technicians, this may be particularly important as a measure that increases their familiarity with the equipment and enables them to ensure that it is used in a safe and effective manner by doctors and hospital staff.

One other major argument that is increasingly made in support of a right to repair is that devices that cannot be repaired are thrown out and end up in landfills. ${ }^{45}$ Aside from the toxic waste, which endangers water supplies and threatens human health, increased manufacturing as a result of short replacement cycles produces significant pollution. ${ }^{46}$ Decreasing the costs of repair, by opening repair markets for competition, is likely to result in a longer average life of devices, as their owners would be more inclined to repair them rather than replace them,

42 Grinvald \& Tur-Sinai, supra note 27, at 292-93; see also Grinvald \& Tur-Sinai, supra note 12 , at $89-91$.

43 For a description of a study exploring user innovation among hospital surgeons, see ERIC VON HipPEL, DEMOCRATIZING INNOVATION 30 (2005) (noting that 22 percent of the respondents reported developing or improving some item(s) of medical equipment for use in their own practices and about half of these innovations were or soon would be marketed by manufacturers of medical equipment). For another example of user innovation by medical personnel, see $i d$. at 79 .

44 Grinvald \& Tur-Sinai, supra note 12, at 89-91.

45 See CBC News, Broken Appliances: Why You May Need Repairs More Often, YouTuBE (Feb. 28, 2020), https://www.youtube.com/watch?v=UwfIbm_JrPI\&app=desktop (interviewing Nathan Proctor, director of the Right to Repair campaign for the public interest advocacy group U.S. PIRG). Environmental concerns appear to be driving the repair movement in the European Union, which has been the most aggressive in legislating for longer end-of-use lifecycles and repair parts availability. See, e.g., Roger Harrabin, EU Brings in 'Right to Repair' Rules for Appliances, BBC News (Oct. 1, 2019), https://www.bbc.com/news/business-49884827. As part of a recent agenda launched by the European Commission to "empower European consumers to play an active role in the green and digital transitions," the Commission noted its intention to "promote repair and encourage more sustainable and 'circular' products." New Consumer Agenda: European Commission to Empower Consumers to Become the Driver of Transition, EuR. Comm'n (Nov. 13, 2020), https://ec.europa.eu/commission/presscorner/detail/en/ ip_20_2069.

46 See Perzanowski, supra note 32 at 363 (discussing the significant pollution caused by manufacturing and global shipping). 
and this would ultimately reduce environmental waste. ${ }^{47}$ This argument seems to apply in the context of medical equipment as well.

Above all, when it comes to medical equipment, in addition to the foregoing rationales undergirding a general right to repair, public health concerns provide a major justification for enabling owners to repair their equipment. The on-site repair of medical equipment is often much quicker than repair by the manufacturer's authorized representatives. ${ }^{48}$ Where a repair can be done by on-site technicians, there is no need to schedule a service appointment with an authorized entity. Correspondingly, there would be no delay in waiting for the appointment to arrive (and during a pandemic, it is likely there are delays or reduction in the ability to provide service by authorized entities). ${ }^{49}$ Importantly, any delay in repairing a broken piece of medical equipment could translate to a decreased level of care for truly sick patients. ${ }^{50}$

In the midst of a global pandemic, the need for timely maintenance and repair of medical equipment is at an all-time high. As the COVID-19 pandemic struck the world, demand for ventilators and other

47 Daniel Moore, You Gotta Fight for Your Right To Repair: The Digital Millennium Copyright Act's Effect on Right-To-Repair Legislation, 6 TEx. A\&M L. REv. 509, 539 (2019) ("Allowing consumers to fix their own devices will reduce the number of broken devices that are thrown out because consumers will use the fixed devices for longer periods, which will decrease the number of disposed devices, therefore reducing environmental damage."); see also Markian Hawryluk, As Ventilators Become Crucial, Repair Roadblocks Remain, FIERCEBIOTECH (Apr. 20, 2020, 7:30 AM), https://www.fiercebiotech.com/ medtech/as-ventilators-become-crucial-repair-roadblocks-remain (quoting Nathan Proctor, expressing the view that " $[\mathrm{w}]$ hen the only company to fix it is the company that made it, that's another incentive for them to get you to buy a new one instead"); Perzanowski, supra note 32, at 4 (arguing that by encouraging consumers to replace their devices rather than repairing them, manufacturers amplify the dire environmental consequences of global electronics production); Chris Jay Hoofnagle, Aniket Kesari \& Aaron Perzanowski, The Tethered Economy, 87 Geo. WASH. L. REv. 783, 819 (2019) (noting that anti-repair moves impose significant environmental harm).

48 See, e.g., PIRG REPORT, supra note 36, at 8 ("[W] hen critical equipment goes out of service, on-site service is sometimes the only option quick enough to serve patients' needs."); Kyle Wiens, Introducing the World's Largest Medical Repair Database, Free for Everyone, IFIXIT (May 19, 2020), https://www.ifixit.com/News/41440/introducing-theworlds-largest-medical-repair-database-free-for-everyone ("Manufacturer service reps can't keep pace with the growing demand for repair of critical hospital equipment. Even if they could, they can't respond as quickly as the biomeds, already at the front lines."); Koebler, supra note 7 (quoting Gay Gordon-Byrne, the executive director of Repair.org, saying that "[i]n the context of ventilators, the on-site biomedical technicians can fix a ventilator in hours and return it to service more quickly than anyone else").

49 See PIRG REPORT, supra note 36, at 8-9.

50 See, e.g., PIRG REPORT, supra note 36, at 8 (interviewing a senior biomedical engineer in a California hospital, who described the experience of going into the hospital in the middle of the night to fix a device that doctors need, while knowing that if "you don't get that device up and running in an hour or two hours, that patient will die"). 
equipment used to diagnose and treat patients surged. ${ }^{51}$ With the pandemic pushing essential equipment into around-the-clock use, accelerated wear-and-tear is likely and the risk of these machines breaking down is tangible.52 At a time like this, timely repair is imperative. Having an option for on-site repair can reduce bottlenecks and provide a healthcare facility with the ability to keep pace with surging demand for equipment.53 Absent an ability to conduct on-site repairs, when a piece of equipment breaks the hospital must either wait for the OEM's authorized technicians to arrive or ship the equipment out-yet, in both cases, this may take too long and have dire consequences. ${ }^{54}$ Simply put, "when any ventilator breaks down amid the surge of cases, waiting two weeks for repair can mean patients die". 55

51 Scher, supra note 36. See also Kyle Wiens, Help Us Crowdsource Repair Information for Hospital Equipment, IFIXIT (Mar. 18, 2020), https://www.ifixit.com/News/36354/ help-us-crowdsource-repair-information-for-hospital-equipment; Hawryluk, supra note 47 (discussing the need to keep ventilators up and running); John Wallace, COVID19 Spotlights Right to Repair Issue, TеснNATion (Mar. 23, 2020), https://1technation.com/covid-19-spotlights-right-to-repair-issue/ (noting that "imaging equipment used to evaluate patients and determine pulmonary conditions is likely to see increased" use during the pandemic).

52 Courtney Linder, Hospitals Need to Fix Ventilators. Why Won't Manufacturers Let Them?, Popular Mechs. (Apr. 16, 2020), https://www.popularmechanics.com/science/ health/a32144222/hospitals-ventilators-right-repair-covid-19/; Wiens, supra note 51; Hawryluk, supra note 47 ("[N]early every ventilator is being called into near-constant service in hot spots, with some pulled out of storage after eight years on the shelf.").

53 See PIRG REPORT, supra note 36, at 3 ("[F] ewer options can lead to bottlenecks, especially in a time of crisis.").

54 See Leticia Reynolds \& Kevin O'Reilly, Opinion: Repairing Ventilators that Can Save Coronavirus Patients Shouldn't Be a Business Decision, MARKETWATch (May 5, 2020, 5:37 PM), https://www.marketwatch.com/story/repairing-ventilators-that-can-save-coronavirus-patients-shouldnt-be-a-business-decision-2020-05-04 (noting that "[i]n the midst of a global pandemic, this model is untenable, and potentially deadly"); An-Li Herring, 'Right-To-Repair' Advocates Worry That Hospitals Can't Fix Broken Ventilators, 90.5 WESA (Apr. 20, 2020, 9:20 AM), https://www.wesa.fm/post/right-repair-advocates-worry-hospitals-cant-fix-broken-ventilators\#stream/0 (Restrictions imposed by OEMs have forced hospitals, in some cases, "to wait days for device makers to send their own repair people.").

55 Hawryluk, supra note 47; see also Reynolds \& O’Reilly, supra note 54 ("With the coronavirus (COVID-19) pandemic pushing ventilators and other essential medical equipment into around-the-clock use, timely maintenance and repair is needed to keep these machines working to save lives."); Scher, supra note 36 ("More maintenance time means less time keeping coronavirus patients breathing."); Letter from the State Treasurers of Pennsylvania, Delaware, Colorado, Rhode Island, Illinois, Massachusetts, Maryland, and California and the State Auditors of West Virginia and Pennsylvania, to equipment manufacturers (May 27, 2020) [hereinafter Treasurers' Letter], https:// masspirg.org/sites/pirg/files/resources/treasurer-Letter-Repair-Manuals\%205.26. 20.pdf ("We are in a public health emergency where every second is vital. In some 
Thus, the need to allow for quick repair enhances the justification to enable hospitals and other healthcare facilities to repair their own machines in times of emergency. COVID-19's high rate of transmission adds more difficulty. Many healthcare facilities are not allowing nonhospital employees-including service representatives-into their facilities, to prevent further spreading of the virus. ${ }^{56}$ At the same time, some OEMs have restricted travel for employees during the pandemic. ${ }^{57}$ The ones that have not done so may need to send their service personnel from one infected hospital to another in a manner that does not align with the efforts to contain the virus. ${ }^{58}$ Rural healthcare providers may face a special challenge in getting quick service from OEMs. ${ }^{59}$ These facilities typically have fewer resources and may be using second-hand equipment without a service contract in effect, and therefore, could also be hit particularly hard by the lack of other options. ${ }^{60}$ Relying exclusively on service contracts with OEMs in this period is also problematic because equipment is being loaned and traded between facilities to accommodate fluctuating needs. ${ }^{61}$

All of this underscores the need to keep other options to repair medical equipment open, rather than relying exclusively on the OEMs'

instances, service contracts have forced hospitals to wait more than a week for a manufacturer's technician to service equipment.").

56 Wallace, supra note 51; PIRG REPORT, supra note 36, at 7; Treasurers' Letter, supra note 55, at 1 ("Hospitals are forced to take their own safety measures, disallowing external technicians to enter their facilities, at the risk of more people coming into direct contact with the coronavirus.").

57 See Wallace, supra note 51; PIRG REPORT, supra note 36, at 7 (quoting a director of clinical engineering at a Dallas-Fort Worth area hospital, who reported that early during the pandemic: "We started calling out for service on some of our devices and vendors were saying that they were not coming in ... we were really hurting at that point, because here we are at the whim of a vendor who says they're not coming in because of COVID19. And we have equipment down and we have patients that still keep coming"); Wiens, supra note 48 (arguing that travel limitations aggravate the problem).

58 See Reynolds \& O'Reilly, supra note 54 (discussing the need for "manufacturer technicians to hop from COVID-infected hospital to COVID-infected hospital").

59 See Wyden and Clarke, supra note 19 (citing Alan Morgan, CEO of the National Rural Health Association: "As COVID-19 surges across rural America, rural providers must have the rapid ability to maintain effective and operational equipment" and enabling on-site repairs by local staff would "enable rural providers caring for COVID patients to keep lifesaving equipment operating during this pandemic").

60 See Treasurers' Letter, supra note 55, at 1 ("We fear that this issue will hurt rural or needy hospitals even harder, as often they may be using secondhand equipment without a maintenance contract or access to a service technician with the manufacturer's repair information. When this equipment breaks down, even needing only minor repairs, it becomes unusable.").

61 See PIRG REPORT, supra note 36, at 9 ("Equipment from various manufacturers is being loaned, shipped and traded between facilities. Ventilators are being retrieved from stockpiles and sent to hospitals for urgent use."). 
authorized technicians. Fortunately, in many hospitals there is a team of biomedical technicians, already "at the front lines," with the requisite skills and training to repair medical devices. ${ }^{62}$ Alas, those technicians often face significant barriers imposed by OEMs that prevent them from doing just that.63 As stated by Gay Gordon-Byrne, Executive Director of the Repair Association, "[e]ven hospital employed biomedical technicians with the best training and qualifications aren't fixing things anymore, they're becoming shipping clerks packaging things to be sent away for repair." 64 While this is not a new phenomenon, in the wake of the pandemic, there have been many reports of hospital personnel running into repair restrictions that prevent them from fixing their own machines. ${ }^{65}$ The next Part will describe these restrictions in greater detail.

\section{REPAIR RESTRICTIONS}

As stated above, hospital or third-party biomedical technicians often face significant problems that restrict their ability to service and repair medical equipment. For the most part, the restrictions are imposed deliberately by OEMs, as part of their efforts to maintain tight control over repair markets.66 This is not a new phenomenon, and in fact, appears to be a long-standing strategy. ${ }^{67}$

To understand the nature and impact of the restrictions, it is important to acknowledge that manufacturers regularly have their own service departments, and employ their own technicians. ${ }^{68}$ These service

62 See Wiens, supra note 48.

63 See, e.g., Koebler, supra note 7 ("As hospitals face the prospect of a critical ventilator shortage caused by the worst public health crisis in a century, they face another problem: not being able to repair the ventilators that they do have.").

64 Id.

65 See, e.g., Reynolds \& O’Reilly, supra note 54 ('[D]espite the urgency of biomeds' work, many of them are running into repair restrictions that can prevent them from doing their job.").

66 See, e.g., Koebler, supra note 7 (Medical equipment has been almost impossible to legally repair because of the manufacturers' exclusive rights over tools, documentation, and replacement parts.).

67 Hawryluk, supra note 47 ("For years, manufacturers of ventilators and other medical equipment have kept a tight grip on the ability of hospitals to service and repair those products.").

68 See Transcript of FDA Workshop on Refurbishing, Reconditioning, Rebuilding, Remarketing, Remanufacturing, and Services of Medical Devices at 34 (Oct. 27, 2016) [hereinafter FDA Workshop, Day 1], http://wayback.archive-it.org/7993/20171115 051259/https://www.fda.gov/downloads/MedicalDevices/NewsEvents/WorkshopsC onferences/UCM532679.pdf (Peter Weems Testimony, describing that manufacturers' service departments encounter challenges when other entities perform improper servicing). 
departments will service their own devices, and sometimes the equipment of other OEMs too. ${ }^{69}$ To make the purchasers or lessees of their equipment utilize these services, OEMs often include servicing or maintenance requirements in their sales contracts. ${ }^{70}$ Outside of these OEM-employed technicians, as discussed in detail below, it is often difficult to obtain service manuals and replacement parts. ${ }^{71}$ This then necessitates reliance on the OEM to service the relevant medical equipment, which as discussed above, can cause delays and increase costs. ${ }^{72}$ While some manufacturers may provide an opportunity for independent technicians to be trained and certified to service their products, the costs of these certification programs are often very high. ${ }^{73}$

With respect to hospitals, the problem is exacerbated, as hospitals often have medical equipment from different manufacturers. ${ }^{74}$ To obtain specific authorization to fix each type of equipment, a hospital would need to have its technicians individually certified for each piece of equipment. ${ }^{75}$ Not only does this make the cost of trainings prohibitive, ${ }^{76}$ the availability of trainings is often restricted, and for

69 See id. at 61-62 (Tara Federici Testimony).

70 See id. at 58 (David Anbari Testimony, describing the practice of "bundling of sales of capital equipment with maintenance contracts which can result in predatory pricing that does nothing more than drives down competition."); id. at 109 (Tim McGeath Testimony: "We have seen OEMs tie agreements for ongoing service and maintenance to the original purchase of equipment, refuse to sell parts unless those parts or repairs are provided by OEM service personnel, refuse to provide service manuals, and even attempt to preclude a purchaser or its agents from performing maintenance or repair on its equipment.").

71 See id.

72 Nathan Proctor, Right to Repair Is a Simple Way to Cut Health Care Costs, U.S. PIRG (Sept. 11, 2018), https://uspirg.org/blogs/blog/usp/right-repair-simple-way-cuthealth-care\%C2\%A0costs; PIRG REPORT, supra note 36, at 5-6, 8-9.

73 See Scher, supra note 36 ("[C]ompanies host their own expensive training programs that take up time and money."); PIRG REPORT, supra note 36, at 8 (citing a biomed, interviewed by U.S. PIRG Education Fund, who said that the maintenance training for one device was $\$ 28,000$-approximately 80 percent of the cost of the whole device (around $\$ 35,000$ )); Scher, supra note 36 (noting that a single certification program for one technician could cost up to $\$ 7,000$, before lost labor time and travel costs). In addition to the cost of the training programs, there is often a cost to purchasing and maintaining the tools needed for specific medical equipment. See FDA Workshop, Day 1, supra note 68, at 67 (Tara Federici Testimony, stating that "[s]ome OEM products require in excess of 90 custom tools along with a custom programmer.").

74 See FDA Workshop, Day 1, supra note 68, at 50 (Anbari Testimony, describing the benefit of having an independent service provider being able to service all of its equipment, as opposed to having to contract with hundreds of manufacturers).

75 See, e.g., Wiens, supra note 51; Scher, supra note 36 (discussing the unfeasibility of getting technicians certified on each and every device); Reynolds \& O'Reilly, supra note 54 (noting that manufacturers often require biomeds to go through costly training to get certified, so hospitals cannot afford to train every technician for every device).

76 PIRG REPORT, supra note 36, at 8 (noting that training costs can be prohibitive). 
some equipment, no training is yet available. ${ }^{77}$ Ultimately, even if a hospital would like to expand training for its biomed staff, price and availability would cause them to ration it.78 Notably, even certified technicians would need to be recertified periodically, and the ability to get it done during a pandemic is naturally restricted. ${ }^{79}$

As indicated above, to maintain their exclusivity and make it difficult for non-certified technicians to repair their devices, medical equipment manufacturers hinder access to service manuals, service keys, schematics, replacement parts, and repair tools. ${ }^{80}$ These repair restrictions are pervasive in the industry. .1

OEMs typically only provide access to repair manuals to their authorized agents, while withholding it from anyone else.82 Even when a manufacturer makes repair information available, it is often a "dumbed-down" version, with schematics necessary for certain repairs only available in the full-service manual kept for its own internal use. 83 Access to diagnostic information is also often restricted by OEMs. ${ }^{84}$

77 Id. (noting that "device-specific trainings are artificially limited" and that "for some equipment, no training is yet available").

78 Id.

79 Id. (sharing the story of a clinical engineering manager, who described the impossibility of complying with the requirement for recertifications in the midst of a pandemic).

80 See, e.g., PIRG REPORT, supra note 36, at 6 (citing Barbara Maguire: "Getting access to tools that we need to do repairs-such as test equipment, test materials, service manuals, parts and training-has always been an issue for us.... Some manufacturers ... restrict our access to the tools that we need.").

81 In a survey that was conducted recently among biomedical technicians, 30.4 percent of the respondents "claimed to have equipment in their facilities which could not be used due to restrictions on spare parts and service information." See PIRG REPORT, supra note 36 , at 9 .

82 See Scher, supra note 36 (noting that the practice of making the manuals inaccessible is a typical "tactic" used by manufacturers); PIRG REPORT, supra note 36, at 6 (quoting James Linton, who runs a college training program for biomedical engineering, who reported that the inability to access manuals is so common that instructing students how to deal with it has become part of his training process); Reynolds \& 0'Reilly, supra note 54 (noting that many manufacturers make it difficult for biomedical technicians to acquire service information). In a survey that was conducted recently among biomedical technicians, 91.8 percent of the respondents "claimed they had been denied service information for 'critical equipment (defibrillators, ventilators, anesthesia machines, imaging equipment, etc.),' with $16.9 \%$ reporting this happens 'Most of the time,' and another $47.5 \%$ reporting this happens 'Somewhat frequently.'" See PIRG REPORT, supra note 36, at 9.

83 See PIRG REPORT, supra note 36, at 11 (reporting GE's practice).

84 See Reynolds \& O'Reilly, supra note 54 (noting that OEMs often required passwords or service keys to access diagnostic information); Kevin O’Reilly, Let Techs Fix Medical Devices: Why the Right to Repair is a Health-Care Imperative, N.Y. Daily News (Aug. 13, 2020), https://www.nydailynews.com/opinion/ny-oped-let-techs-fixmedical-devices-20200813-doiiblytyfds7knll25cdb3xsm-story.html (reporting that 
The OEMs' grip has prompted under-the-table sharing of information between biomedical technicians. ${ }^{85}$ Repair manuals and other information can sometimes be found in certain online forums. ${ }^{86}$ But to locate such information, these technicians must waste precious time. ${ }^{87}$ Once again, the challenge mounts when biomedical technicians face a wide variety of machines made by a number of different manufacturers. ${ }^{88}$ As Kyle Wiens, the CEO of iFixit, a company promoting consumers' right to repair and selling repair parts, reported: "[B]iomeds spend innumerable hours courting the internet, searching for crucial repair information they need to make a fix or perform preventative maintenance."89 During the COVID-19 pandemic, hospital technicians have apparently turned to these decentralized information-sharing forums increasingly often..$^{90}$

Unfortunately, not only are these self-help measures inefficient, but OEMs are attempting to curtail them by relying on copyright law. The story of Frank's Hospital Workshop provides a good illustration of this. ${ }^{91}$ A biomedical technician living in Tanzania known as "Frank" has found that most of the hospitals he works for in this developing region have a large percentage of broken medical equipment and little or no access to training or service information. He created a website where he publicly posts hundreds of manuals and other useful repair information to assist these hospitals to repair their aging devices in an attempt to give them

manufacturers refuse to provide biomeds with diagnostic passwords); PIRG REPORT, supra note 36, at 3 (noting the restricted access to information necessary to read error logs or run diagnostic tests).

85 See, e.g., Hawryluk, supra note 47.

86 See, e.g., Reynolds \& O'Reilly, supra note 54 (providing a few examples for forums that serve as common places for biomedical technicians to turn when in need of service information or passwords).

87 See Wiens, supra note 51 ("Our biomed technicians' time is too precious to waste on internet Easter-egg hunts."). Even when information is found, it is often not complete or is in a foreign language. See, e.g., Reynolds \& O'Reilly, supra note 54 ("Despite an active community, sometimes the best that a biomed can find is a manual in Turkish.").

88 See Wiens, supra note 51 (noting that to get repair information in such cases, technicians would have to search all over the web and they will not always be able to find what they are looking for).

89 Wiens, supra note 48.

90 See Paul Detrick, Hospital Technicians Ignore Copyright Law to Fight COVID-19, REASON (Apr. 13, 2020), https://reason.com/video/2020/04/13/hospital-techniciansignore-copyright-law-to-fight-covid-19/ (reporting that absent service manuals, BMETs resort to online forums and rely on intuition, and noting that while they have done it for years, during the COVID-19 pandemic this practice has grown).

91 See Hawryluk, supra note 47; Linder, supra note 52; Wiens, supra note 51; Device Companies Are Cutting Hospitals Out of the Loop, REPAIR Ass'N, https://www.repair.org/medical (last visited Oct. 27, 2021). 
a few extra years of life. ${ }^{92}$ Alas, certain manufacturers keep sending him legal threats and take-down notices, demanding that he removes their manuals. ${ }^{93}$ Recently, the German ventilator manufacturer Dräger sent cease-and-desist letters to Frank's, ${ }^{94}$ and now, in place of some formerly available service manuals, a warning appears: "Download prohibited by Dräger. Support is not desired." 95

iFixit ran into a similar problem after creating a "Medical Device Repair Database" and posting it as part of its repair information website. ${ }^{96}$ Hundreds of volunteers helped creating the database following a crowdsourcing campaign led by iFixit, and it includes documentation for mission-critical devices relevant to the COVID-19 pandemic. ${ }^{97}$ A short time after iFixit posted the database, Steris, a manufacturer of medical sterilizers used to prevent contamination, sent a request to iFixit demanding it to take down installation and maintenance manuals relating to their devices on copyright grounds. iFixit, represented by the Electronic Frontier Foundation ("EFF"), resisted the request, arguing that its activity is non-infringing. ${ }^{98}$

Another aspect that stymies repair of medical equipment is the use of technical protection measures by the OEMs. Medical devices, including ventilators, have gotten more complicated over the years and many of them are now controlled by software. 99 Device manufacturers often put an "electronic security lock" on the software, to prevent nonauthorized third parties from accessing the software and servicing the

92 Frank's Hosp. WorkSHOP, http://www.frankshospitalworkshop.com (last visited Oct. 27, 2021).

93 See Device Companies Are Cutting Hospitals Out of the Loop, supra note 91 (noting that Weyer, General Electric, and other manufacturers regularly send Frank legal threats and take-down notices).

94 Linder, supra note 52.

95 Equipment, Frank's HoSP. WorKsHOP, http://www.frankshospitalworkshop.com/ equipment/ventilators_service_manuals.html (last visited Oct. 27, 2021) (choose "Ventilators" on side bar; then choose "Service Manuals").

96 Medical Device Repair, IFIXIT, https://www.ifixit.com/Device/Medical_Device\# main (last visited Oct. 27, 2021).

97 See Wiens, supra note 51; Wiens, supra note 48 (introducing the database); Walsh, supra note 11.

98 Letter from Electronic Frontier Foundation, to Steris, on behalf of iFixit (May 26, 2020) [hereinafter EFF Letter], https://www.eff.org/document/letter-eff-steris-behalfifixit-5-26-2020.

99 Koebler, supra note 7; see also Anthony Rosborough, Unscrewing the Future: The Right to Repair and the Circumvention of Software TPMs in the EU, $11 \mathrm{~J}$. INTELL. PROP. INFo. TECH. \& E-CoM. L. 26, 30 (2020) (arguing that the range of products that are becoming increasingly unserviceable because of software integration is broadening and noting that "[i]n the context of the current global health pandemic, respiratory ventilators and other medical equipment essential for combating COVID-19 are subject to myriad software TPMs which present challenges for healthcare providers and technicians."). 
device. ${ }^{100}$ While these locks are typically vulnerable to hacking by those with sufficient know-how, Section 1201 of the Digital Millennium Copyright Act makes it illegal to disable a technological protection measure used by a copyright owner to protect its software.101 Even if repair is somehow possible, manufacturers often install additional measures that block the ability to use the device following an unauthorized repair. 102

The ability of independent technicians to conduct maintenance and repair of medical equipment is also hindered at times because of restricted access to repair and diagnostic tools. ${ }^{103}$ In addition, many manufacturers refuse to sell service parts to potential competitors in the market for repair services. ${ }^{104}$ Another strategy often employed by manufacturers is designing their equipment so that they require calibration software to activate new replacement parts before usesoftware that, needless to say, is not provided to hospitals or independent technicians. ${ }^{105}$ Absent reasonable access to repair tools and replacement parts, some professionals resorted to making them on their own.106 One technology that seems particularly suited for this during emergency times is 3D printing, being quick and cheap and not requiring a big manufacturing factory. ${ }^{107}$ Alas, in order to $3 \mathrm{D}$ print a

100 See Koebler, supra note 7; Rosborough, supra note 99; Linder, supra note 52; PIRG REPORT, supra note 36 , at 3.

10117 U.S.C. $\$ 1201$.

102 See PIRG REPORT, supra note 36, at 3 (noting that a common practice across the medical equipment industry is requiring calibration software to complete repairs); see also Grinvald \& Tur-Sinai, supra note 12, at 79.

103 See, e.g., Reynolds \& O'Reilly, supra note 54 (discussing the importance of having "test equipment and diagnostic tools"); PIRG REPORT, supra note 36, at 6 (interviewing Barbara Maguire).

104 See PIRG REPORT, supra note 36, at 11 (noting that these are the same tactics used widely in the consumer electronics, agricultural equipment and home appliance industries"); id. at 9 (In a survey that was conducted recently among biomedical technicians, " $88.7 \%$ of respondents reported that manufacturers had refused to sell them spare parts, with 4.5\% reporting this happens 'Most of the time,' $36.2 \%$ reporting this happens 'Somewhat frequently,' and $48.0 \%$ reporting this happens, 'Sometimes, but infrequently.'”); Wallace, supra note 51 (quoting David Francoeur).

105 Reynolds \& O'Reilly, supra note 54; PIRG REPORT, supra note 36, at 7.

106 See, e.g., Koebler, supra note 7 (noting that some professionals have resorted to making DIY parts); Amy Feldman, Meet the Italian Engineers 3D-Printing Respirator Parts for Free to Help Keep Coronavirus Patients Alive, Fonbes (Mar. 19, 2020, 3:57 PM), https://www.forbes.com/sites/amyfeldman/2020/03/19/talking-with-the-italian-engineers-who-3d-printed-respirator-parts-for-hospitals-with-coronavirus-patients-forfree/?sh=7c948b1578f1 (reporting the case of a start-up company in Italy engaging in 3D printing of valves for respirators to address a severe shortage in such parts).

107 See Feldman, supra note 106 ("[T]he technology of 3D printing, which allows digital design of parts and the 'printing' of them off a machine that creates them layer by layer, is ideally suited to emergency manufacturing because it is fast, cheap and can be 
part, one would need the relevant computer-aided design ("CAD") file, which manufacturers are likely to refuse sharing. 108 Even if someone managed to manufacture or print a part-for instance, by reverseengineering an original part and creating the CAD file independentlythis can trigger patent liability when manufacturers hold patents over such parts. ${ }^{109}$

As mentioned above, OEMs have continued to impose these barriers on the ability to maintain and repair their devices during the pandemic, and hospitals around the country have faced problems while trying to repair ventilators and other medical equipment. To determine how widespread repair restrictions are and the extent to which restrictions impacted work under the stress of COVID-19, U.S. PIRG Education Fund, a nonprofit research and advocacy organization, surveyed 222 biomedical professionals. Nearly half reported they had been denied access to "critical repair information, parts or service keys" since March 2020.110 The difficulties faced by hospital technicians throughout the first months of the pandemic have caught public attention.111 In April 2020, U.S. PIRG collected and delivered more than 43,000 petition signatures to ventilator manufacturers urging them to provide easy access to repair and maintenance documentation. $112 \mathrm{~A}$ group of state treasurers and auditors issued a similar call on manufacturers to release information and allow hospitals to use

done without a big factory."). See generally Ghilherme Arthur Longhitano et al., The Role of 3D Printing During Covid-19 Pandemic: A Review, 6 Progress In Additive MFg. 19 (Nov. 24, 2020), https://link.springer.com/article/10.1007/s40964-020-00159-x (discussing the use of 3D Printing technologies during the pandemic).

108 See, e.g., Moody, supra note 10 (describing how the manufacturer refused to share the relevant CAD file with the Italian company that asked to manufacture the valve).

109 See id. (discussing the impact of potential patent litigation, although in the specific case at hand it appears that the manufacturer did not threaten to sue); Feldman, supra note 106.

110 PIRG REPORT, supra note 36, at 10 (" $48.8 \%$ report they have been denied access to 'critical repair information, parts or service keys' [for medical equipment] since March."). The survey respondents have also been asked questions specific to repair of ventilators. See id. at 9-10 ("69.5\% of the respondents handle ventilator repair within their departments. Of those that work with ventilators, $29.2 \%$ report that they currently have ventilators that they cannot use because they lack access to parts and service information. $24.2 \%$ of those technicians reported that they had been denied access to ventilator repair information, training, parts or service keys since March [2020], and $51.9 \%$ report that they have ventilators they could not service on-site if they broke.").

111 Reynolds \& O’Reilly, supra note 54.

112 Id.; News Release, 43,000 Call on Ventilator Manufacturers to Release Repair Information, U.S. PIRG (Apr. 3, 2020), https://uspirg.org/news/usp/43000-call-ventilatormanufacturers-release-repair-information. 
technicians of their choice.113 Some manufacturers made certain socially responsible changes to their repair policies because of the pandemic and the public outcry.114 GE, for example, provided access to the technical reference manuals and PC service applications for certain ventilator models while waiving the four-day in-person training usually required before providing such materials. ${ }^{115}$ Similarly, Medtronic, the largest medical device company in the world, ${ }^{116}$ released schematic designs for an older ventilator model.117 Yet, by and large, repair restrictions have remained ubiquitous. ${ }^{118}$

To summarize, this Part has illustrated the difficulties faced by repair staff in hospitals and other healthcare facilities across the U.S. in their struggle to keep equipment up and running during the pandemic. To a large extent, these difficulties stem from restrictions on access to what technicians need in order to diagnose, maintain, and repair medical equipment. Such restrictions seem to be imposed by OEMs primarily as part of their efforts to secure their control in repair markets. To keep equipment working, some repair professionals sometimes resort to self-help measures, like printing replacement parts or sharing repair manuals, but these efforts have triggered legal threats by OEMs, based primarily on intellectual property grounds. Notably, such threats can create a chilling effect on the repair ecosystem even if

113 Treasurers' Letter, supra note 55; see also Reynolds \& O’Reilly, supra note 54; Susan Decker, Broken Ventilators Spark Push to End Limits on Who Can Fix Them, BloomBerg (May 16, 2020), https://www.bloomberg.com/news/articles/2020-05-16/ broken-ventilators-spark-push-to-end-limits-on-who-can-fix-them.

114 See Reynolds \& O'Reilly, supra note 54; Scher, supra note 36 ("Some ventilator manufacturers have eased up on the requirements.").

115 ICU Ventilation Use Resources, GE HEALTHCARE, https://www.gehealthcare.com/ products/icu-ventilation-user-resources (last visited Sept. 12, 2021) (recommending that the procedures described in these resources should only be performed by trained service professionals. GE also promised to make performance support videos accessible during the emergency at no cost.).

116 Hannah Burke, Who Are the Top 10 Medical Devices Companies in the World (2021)?, Proclinical (Aug. 18, 2021), https://www.proclinical.com/blogs/2021-8/whoare-the-top-10-medical-device-companies-in-2021.

117 See Hawryluk, supra note 47 (noting, however, that technicians report still having trouble accessing service manuals for Medtronic's top-of-the-line ventilators); see also News Release, Statement: After Public Outcry, Ventilator Repair Restrictions Loosen, U.S. PIRG (Apr. 22, 2020), https://uspirg.org/news/usp/statement-after-public-outcryventilator-repair-restrictions-loosen (listing other examples of companies making positive changes in their repair policies).

118 See PIRG REPORT, supra note 36, at 3; Reynolds \& O’Reilly, supra note 54; News Release, Five State Treasurers Call on Ventilator Manufacturers to Remove Repair Restrictions, U.S. PIRG (Apr. 14, 2020), https://uspirg.org/news/usp/five-statetreasurers-call-ventilator-manufacturers-remove-repair-restrictions (noting that "so many companies have increased their repair restrictions in recent years, that the repair ecosystem is fragile in this time of crisis"). 
not issued or pursued regularly. In light of the strong justifications for a right to repair explored in Part II of this Article, a response of the legal system seems warranted. To enable quick maintenance and repair of medical equipment, any barriers that prevent hospital technicians from operating must be eliminated. We turn our attention to the most recent response from policymakers in the next part.

\section{THE PROPOSED FEDERAL LEGISLATION}

To directly and explicitly address the difficulties faced by independent biomedical technicians, in August 2020 Senator Ron Wyden and Representative Yvette D. Clark introduced in the Senate and the House a "right to repair" bill that would allow emergency repairs of medical equipment.119 The proposed act (the "Act") was entitled the "Critical Medical Infrastructure Right-to-Repair Act of 2020."120 Unfortunately, the Act did not advance out of committee in either of the Congressional chambers and therefore "died" when the 116th Legislative Session ended. ${ }^{21}$ But the Act marked the first attempt to take action in Congress to facilitate a right to repair medical equipment, and moreover, to address many of the pertinent intellectual property issues. ${ }^{122}$ In light of this, and in hopes that the Act (or something similar to it) may be reintroduced in a future session, it is important to critically analyze its substance.123 In Part IV, we provide a description of the Act's major provisions and then turn to a critical analysis of those provisions in Part V.

The first thing to note is the Act's limited temporal scope. In attempting to gain traction with the Act, the sponsors emphasized that it was designed to serve as a "time-limited" solution. ${ }^{124}$ Indeed, the Act would have applied only during a "covered emergency," which it defined as "the public health emergency declared by the Secretary of Health and Human Services ... on January 31, 2020, with respect to the Coronavirus

119 See Wyden and Clarke, supra note 19.

120 Id.

121 See the Act, supra note 15.

122 See Wyden and Clarke, supra note 19 (limiting copyright and patent rights to allow for repair).

123 It is important to note that the "Fair Repair Act," introduced into the House of Representatives by N.Y. Congressperson Joseph Morelle in June 2021, specifically exempts medical devices. See supra note 17.

124 See Wyden and Clarke, supra note 19 (quoting Sen. Wyden, who presented the bill as designed to not tie the hands of technicians "until this crisis is over," and Rep. Clarke, who emphasized that this is a "narrowly-tailored, common-sense, and time-limited bill"). 
Disease 2019 (COVID-19), including any renewal of that declaration."125 This important feature of the Act will be discussed further below. ${ }^{126}$

The Act tackled the issue at hand in two principal manners. First, it restricted the ability of OEMs to rely on certain intellectual property rights or on contracts to prevent others from repairing or maintaining "critical medical infrastructure," defined broadly to include "a device, computer program, or other product or equipment used to provide medical services."127 Second, it required OEMs to provide, on fair and reasonable terms, access to information and tools used to diagnose problems and service, maintain, or repair medical equipment. Each of these major provisions will be discussed in turn.

\section{A. Suspending IP and Contractual Restrictions}

Sections 3 through 5 of the Act sought to suspend certain intellectual property restrictions, which impede the right to repair. These sections addressed both copyright law and design patent law, as well as potential contractual restrictions on repair.

Regarding copyright law, the Act would have added a limitation to the exclusive rights of the copyright owner by inserting a new section 123 in the Copyright Act. Under the proposed limitation, during the declared COVID-19 emergency, it would not have been considered copyright infringement where a "covered service provider"128 made (or authorized the making of) a copy of their "service materials"129 incidental to the repair or maintenance of critical medical infrastructure

125 Critical Medical Infrastructure Right-to-Repair Act of 2020, S. 4473, 116th Cong. $\S 3(a)(1)$ (2020). The Secretary's declaration was made pursuant to the Public Health Service Act, 42 U.S.C. § 247 d.

126 See infra Part V.

127 S. $4473 \S 3(\mathrm{a})(1)$.

128 Id. (defining covered service provider as "(A) the owner or licensee of a copy of service materials; or (B) the agent of a person described in subparagraph (A).").

129 The term "service material[s]" is broadly defined in the Act, as "any information or material that the manufacturer ... provides" to its technicians or authorized repair facilities to diagnose, service, maintain, repair, activate, certify, or install a medical device, or any replacement part or equipment related to that device, as well as training materials. Id. $\S 3$. The Act clarified that "service material[s]" include, among other things: (i) "schematics, wiring diagrams, mechanical layouts, and other pertinent data;" (ii) computer programs used for diagnostic purposes, or for calibrating, repairing, or maintaining the equipment; (iii) "service keys ... required to access diagnostic information and otherwise authorize repairs"; (iv) "error logs ... required to diagnose required repairs"; (v) "preventative and corrective maintenance, inspection, and repair procedures"; and (vi) "information regarding safety alerts, recalls, service bulletins, specification updates, and the need for adjustments to maintain efficiency, safety, and convenience with respect to" the relevant device. Id. 
as part of a response to the COVID-19 emergency.130 The Act further clarified that the actions explicitly authorized under this new limitation could still be permitted under other provisions of the Copyright Act.131 This is an important rule of construction, as making copies of service materials in these circumstances may sometimes be protected under the fair use defense. ${ }^{132}$

The Act also addressed the Copyright Act's anti-circumvention provisions. These provisions prohibit the circumvention of technological protection measures controlling access to copyrightprotected works, and the manufacturing and trafficking in technology designed to circumvent such measures. ${ }^{133}$ Many electronic devices incorporate some type of technological protection measure ("TPM") to limit access to the device and its software. ${ }^{134}$ Where an independent service technician is servicing, maintaining, or repairing a device without authorization from the OEM, they likely do not have the special software or codes needed to unlock the TPM and may need to "hack" into the device. Such an action is in violation of the Copyright Act and can be subject to civil and criminal penalties. ${ }^{135}$

Under the Act, however, a "covered healthcare provider"-i.e., the owner, lessee, or licensee of critical medical infrastructure, or its agent-would be permitted to both circumvent these technological protection measures (i.e., legal hacking), and manufacture or traffic in technology designed to circumvent measures, in preparation for, or as a response to, the emergency. 136 This latter provision could be significant where independent service technicians do not know how to hack, in which case they could try finding assistance online. Yet, software experts who figure out how to hack and then post those hacks on the internet are considered "traffickers" and, even with this provision, it is unclear whether these experts (if they were not themselves a "covered healthcare provider") would be infringing under the Copyright Act. 137 The Act clarified that this suspension for covered healthcare providers would not prevent the Librarian of Congress from granting exemptions

130 The term "repair" is defined as restoring the "critical medical infrastructure to a state that is in accordance with its original specifications ... including any changes to those specifications that are issued by the manufacturer." Id.

131 Id.

132 See discussion infra notes 172-186 and accompanying text.

13317 U.S.C. $\S 1201$.

134 See Grinvald \& Tur-Sinai, supra note 12, at 104.

13517 U.S.C. $§ 1201 ; 17$ U.S.C. $§ 1203$ (discussing civil penalties); 17 U.S.C. $§ 1204$

(outlining criminal penalties).

136 S. $4473 \S 3(\mathrm{a})(2),(3)$.

137 See, e.g., Universal City Studios, Inc. v. Corley, 273 F.3d 429 (2d Cir. 2001). 
pursuant to its general authority to do so under the anti-circumvention provisions. ${ }^{138}$

Regarding patent law, the Act proposed to exempt covered healthcare providers from design patent infringement if they fabricate a part on a non-commercial basis, and as needed, for the repair or maintenance of critical medical infrastructure, if the repair or maintenance is part of a response to the covered emergency. ${ }^{139}$

In addition to these intellectual property-based restrictions, the Act also dealt with contractual restrictions on repair. In this regard, the Act proposed to nullify any contract provision that prohibits or restricts a covered healthcare provider from repairing or maintaining critical medical infrastructure in response to the emergency. ${ }^{140}$

\section{B. Mandating Access}

The second part of the Act would have placed certain affirmative duties on original manufacturers to ensure an effective implementation of the right to repair medical equipment. ${ }^{141}$ These duties would have been imposed on any manufacturer of critical medical infrastructure sold, leased, or otherwise introduced to commerce in the United States. ${ }^{142}$ Under the proposal, the manufacturer of such a piece of equipment shall provide owners, lessees, or service providers with access to service materials that are required to (1) diagnose problems with respect to that equipment, and (2) service, maintain, or repair it.143 "Service provider" was to mean "any person engaged in the diagnosis of problems with respect to, or the service, maintenance, or repair of, critical medical infrastructure." 144 Such access would have had to be offered on fair and reasonable terms. ${ }^{145}$

In addition, manufacturers would have had to offer for sale to the owners or lessees of the critical medical infrastructure, and to all service providers, on fair and reasonable terms, any tool (including software)

\footnotetext{
138 S. $4473 \S 3(\mathrm{~b})(4)(B)$. Under 17 U.S.C. $\S 1201(\mathrm{a})(1)(\mathrm{C})$ and (D), the Librarian of Congress can grant temporary exemptions from the prohibition against circumvention under certain conditions. But note that under these provisions, Congress did not authorize the Librarian to grant exemptions to the anti-trafficking prohibition. See also U.S. Copyright Office, Section 1201 Rulemaking: Seventh Triennial Proceeding to Determine Exemptions to the Prohibition on Circumvention 5 (2018).

139 S. $4473 \S 4$.

140 Id. $\S 5$.

141 Id. $§ 6$.

142 Id. $\S 6(\mathrm{~b})$.

143 Id. § 6(b).

144 Id. $\S 2(5)$.

145 For the meaning of this term, see infra notes 148-149 and accompanying text.
} 
and equipment for the diagnosis, service, maintenance, or repair of the critical medical infrastructure. ${ }^{146}$ Manufacturers would have also had to provide all information that enabled after-market tool companies to manufacture tools with the same functional characteristics as those made available by the manufacturer to authorized dealers. ${ }^{147}$

The phrase "fair and reasonable terms" used in the foregoing provisions is defined in the Act, as follows. With respect to the provision of access to service materials in the form of documentation, "the term 'fair and reasonable terms' means at no charge, except that if the applicable service provider requests documentation in physical printed form, the term ... includes a charge ... for the reasonable actual costs of preparing and sending the documentation." 148 In all other contexts, the phrase "fair and reasonable terms" refers to such

costs and terms that are equivalent to the most favorable costs and terms offered by that manufacturer to [authorized] repair facilities[,] ... (A) using the net costs that would be incurred by that repair facility in obtaining an equivalent part, tool, or documentation; and (B) taking into consideration any discount, rebate, or other incentive offered by the manufacturer. ${ }^{149}$

The Act addressed the potential conflict between the affirmative duties imposed on OEMs and trade secret law. Trade secret law is a form of intellectual property law that protects information or know-how that has been appropriately safeguarded by its owner from misappropriation by others. ${ }^{150}$ As proposed in the Act, a manufacturer would not be required to publicly disclose information that, if made public, would divulge methods or processes entitled to trade secret protection under federal trade secret legislation (the Defend Trade Secrets Act). But a manufacturer "may not withhold information" on this ground "if that information is provided directly or indirectly to authorized dealers or service providers." 151

Under the proposed Act, the Federal Trade Commission ("FTC") was to have exclusive authority to enforce compliance with these requirements. ${ }^{152}$ The FTC was also to "have authority ... to promulgate any regulations necessary to implement" these provisions. ${ }^{153}$

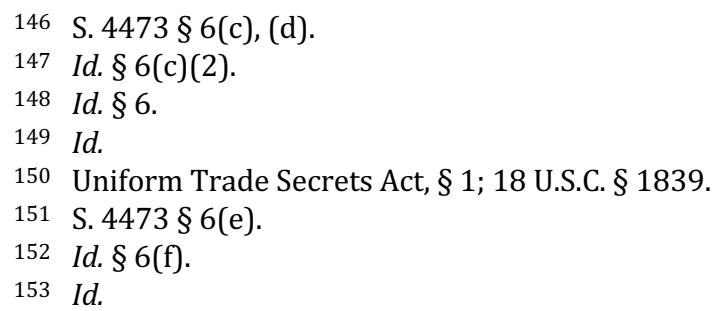




\section{CRITICAL DISCUSSION}

\section{A. The Act}

The legislative initiative leading to the proposed Act is highly commendable. If the Act is re-introduced and enacted in the coming year, it would go a long way in facilitating a right to repair medical equipment during the pandemic. As discussed in Part II of this Article, enabling repairs outside the circle of the manufacturers' authorized technicians, particularly at this time, is of utmost importance, and as Part III demonstrated, absent legal intervention, it is highly doubtful whether such a result could be achieved in the free market.

Notably, this is the first time that right-to-repair legislation has been introduced at the federal level, and this may pave the way for similar initiatives in the future. ${ }^{154}$ Most importantly, the Act acknowledges the central role that intellectual property law may play in curtailing a right to repair, ${ }^{155}$ and tackles the various ways in which OEMs utilize intellectual property rights to maintain tight control of the repair market. Admittedly, to continue moving in this direction, the legislation must first be re-introduced in the current Congressional session. Beyond that, there are also some aspects of the proposed legislation that could be improved. For instance, in the context of exempting healthcare providers from patent liability for fabricating a part as needed for maintenance or repair, it may be advisable to address utility patents in addition to design patents. ${ }^{156}$ As another example, the affirmative duties of manufacturers should include a duty to provide access - on fair and reasonable terms - to CAD files that can serve as blueprints for replacement parts. ${ }^{157}$ While not an exhaustive list, such

154 Matthew Gault \& Jason Koebler, Congress Will Consider National Right-to-Repair Legislation for Medical Equipment, VICE (Aug. 6, 2020), https://www.vice.com/en/article/akzyy5/congress-will-consider-national-right-to-repair-legislation-for-medicalequipment. But see Promoting Automotive Repair, Trade and Sales (PARTS) Act, H.R. 1879, 115th Cong. (2017). If passed, the PARTS Act would create a narrow exception from design patent infringement for collision repair parts for cars. Similar legislation was introduced in the 114th Congress. See PARTS Act, S. 560, 114th Cong. (2015). For discussion, see Joshua D. Sarnoff, White Paper on Protecting the Consumer Patent LaW Right of Repair And the Aftermarket for Exterior Motor Vehicle RePair Parts: The PARTS ACT, S. 812; H.R. 1879, 115TH ConGRESS (2017), https://papers.ssrn.com/sol3/papers. cfm?abstract_id=3082289.

155 See generally Grinvald \& Tur-Sinai, supra note 12 (highlighting the need to address intellectual property concerns to secure an effective right to repair).

156 As stated above, the proposed Act only addressed design patents. See supra note 139 and accompanying text.

157 For the proposed definition of service materials, which did not seem to cover CAD files, see supra note 129. 
changes could strengthen the Act and close loopholes standing in the way of an effective right to repair.

One important feature of the Act that deserves deeper contemplation is its temporary nature. 158 The temporal limit could arguably be justified to the extent that the need for legal intervention underlying the Act is directly related to the emergency situation at hand. Given the critical need to enable repair during this pandemic, one could say it is the only need worth addressing right now. Indeed, if there was no need for suspending or limiting intellectual property protection before the pandemic, enacting time-limited legislation could be justified as allowing Congress to deal with the unique challenges of the moment without deviating from longstanding norms. Yet this is not the case. Instead, as discussed in Part II above, there are strong justifications for securing a general right to repair medical equipment on a more permanent basis. 159

Still, various scholars identified several advantages to the mechanism of temporary legislation even in cases where a long-lasting legal solution is ultimately sought. Among other things, temporary legislation may lead to better-informed regulation, particularly for newly recognized risks, by spreading decision costs over time and enabling policymakers to incorporate more information into legislative judgments. ${ }^{160}$ Relatedly, temporary legislation enables testing and experimenting with legal policy. ${ }^{161}$ One other advantage of temporary law is in decreasing the costs of political struggles and serving as a form of political compromise. ${ }^{162}$

These advantages of temporary legislation seem to be applicable in the context of the Act. Restricting the scope of the regulation to times of pandemic would most likely decrease opposition on behalf of OEMs and

158 See supra notes 124-125 and accompanying text.

159 See supra Part II.

160 Jacob E. Gersen, Temporary Legislation, 74 U. CHI. L. REv. 247, 248 (2007); see also Tom Ginsburg, Jonathan S. Masur \& Richard H. McAdams, Libertarian Paternalism, Path Dependence, and Temporary Law, 81 U. CHI. L. REv. 291, 299 (2014) (discussing the advantages of temporary legislation when "the status quo is trapped in an inefficient" equilibrium as a result of path dependence and when "there are information barriers to identifying the superior equilibrium").

161 See Ittai Bar-Siman Tov, Temporary Legislation, Better Regulation and Experimentalist Governance: An Empirical Study, 12 REgul. \& GovernANCE 192, 192 (2018) (noting that temporary legislation "is often viewed as a key tool for experimentalist governance approaches").

162 Ginsburg et al., supra note 160, at 297-98 (explaining that "[p]roponents of regulation will accomplish their goal but will, by accepting an expiration date, bear the costs of extension," while "[o]pponents of regulation will be less opposed to temporary rules than permanent ones"). 
make the prospect of adopting the Act more politically feasible. For these reasons, it is also likely that throughout the legislative process there would be less of a need to compromise on the scope of the rights provided to healthcare facilities and third-party servicers under the legislation. Importantly, enacting emergency legislation does not bar the possibility of renewing it with or without modifications at some point and perhaps would even serve as a foundation for future, broader legislation. Hopefully, during the limited period when the Act would be in force, sufficient information would be gathered that could serve to negate opinions biased against it, including those related to patient safety and cybersecurity concerns, discussed below. 163 To make it work, though, any reintroduced Act should include an assessment mechanism. ${ }^{164}$

On the other hand, temporary legislation has two main disadvantages, which may be relevant in the current context. First, temporary legislation may cause uncertainty and reduce the ability of market players to rely on it. ${ }^{165}$ In the case at hand, given the temporary nature of the provisions, hospitals may be hesitant to rely too heavily on the safe harbor the Act provides them by investing too many resources into repair infrastructure. The second point involves where the burden of future change falls. Such a burden is generally laid on the opponents of legislation, who must secure repeal in the case of permanent legislation, but in the case of temporary legislation, it is laid on the proponents of the law, who must secure renewal. ${ }^{166}$ In the present situation, pro-repair advocates would bear a particularly heavy burden in attempting to secure renewal or broaden the Act, in light of the difficulty of amending intellectual property laws to restrict the scope of rights. ${ }^{167}$ As the current struggle brings the issue of repairing medical

163 See infra Section V.C.

164 Such a mechanism was included in the original Act. Critical Medical Infrastructure Right-to-Repair Act of 2020, S. 4473, 116th Cong. $\$ 7$ (2020) (requiring the FTC to work with other agencies to study the impact and effectiveness of the Act and report to Congress no later than one year after the enactment of the Act).

165 See Shmuel I. Becher, Key Lessons for the Design of Consumer Protection Legislation, in LAW \& ECONOMICS OF REGULATION 91, 92 (Klaus Mathis \& Avishalom Tor eds., 2021).

166 See Ginsburg et al., supra note 160, at 300 (presenting this tradeoff). In fact, this is exactly the situation that proponents of exemptions from the Digital Millennium Copyright Act (DMCA) face in the triennial rulemaking process at the U.S. Copyright Office. See U.S. Copyright OFF., Eight Triennial Section 1201 Proceeding (2021), https:// www.copyright.gov/1201/2021/ (last visited July 30, 2021). See also supra note 138 and accompanying text.

167 See generally Christopher M. Holman, Biotechnology's Prescription for Patent Reform, 5 J. Marshall Rev. Intell. Prop. L. 318, 325 (2006) (noting that the biotechnological industry "is against virtually all of the major proposed reforms [to patent law] that would weaken patents or restrict the rights of patent holders."); Jay P. 
equipment to the forefront in an unprecedented manner, this may be a particularly good opportunity to try implementing more permanent changes in intellectual property laws.

One compromise worth considering is to enact legislation that would apply in emergency situations, not just the current COVID-19 pandemic. In other words, the term "covered emergency" could be defined more broadly, in a manner that would cover similar occurrences as well. This would enable preparedness of the intellectual property system for the future, rather than having to "reinvent the wheel" and waste precious time should the need arise again. 168

\section{B. Non-Legislative Solutions}

Alongside the proposed legislation, there are certain other directions that should be pursued to advance the right to repair medical equipment. ${ }^{169}$ Discussion of such non-legislative measures is important for various reasons. First, there is no guarantee that the Act or any new version of it would be enacted. Second, even if the Act is ultimately enacted, there is a need for measures that could provide some interim relief to the repair ecosystem. ${ }^{170}$ Third, if the legislation is enacted as currently drafted, so that it applies only during the COVID-19 emergency (or in a somewhat expanded manner, in other emergencies as well), there is still a need for solutions that would be applicable in other, more normal, periods. Fourth, the measures proposed herein could serve as supplementary measures alongside the Act.

The main path that should be pursued-regardless of whether the legislation passes or not-is judicial application of certain policy levers

Kesan \& Andres A. Gallo, The Political Economy of the Patent System, 87 N.C. L. REv. 1341, 1353-61 (2009) (discussing the lobbying efforts on behalf of pharmaceutical companies in order to maintain a strong patent system).

168 Other scholars advocate for a broader definition and applicability. See supra note 20 and accompanying text.

169 While in this section we focus on non-legislative measures, one other direction that could have a significant impact alongside the push for federal legislation is to continue the efforts to enact state "right to repair" legislation that covers medical equipment alongside other types of electronic devices. See supra notes 22-26 and accompanying text. Notably, the proposed state repair laws only tackle the issue from a consumer protection angle. The laws would mandate disclosure of repair information and access to parts and tools, and nullify restrictive contractual provisions, but would not deal with any intellectual property matters under the domain of federal law.

170 Particularly where such laws are likely to be challenged in court, as happened in connection with the Massachusetts update to the right to repair automotive law. See Nate Raymond, Auto Group Goes to Trial to Challenge Massachusetts Vehicle Data Law, REUTERS (June 14, 2021, 3:23 PM), https://www.reuters.com/business/legal/autogroup-goes-trial-challenge-massachusetts-vehicle-data-law-2021-06-14/. 
within intellectual property law in a "repair-friendly" manner.171 A prominent example for such a policy lever is the fair use doctrine in copyright law. Under Section 107 of the Copyright Act (the "fair use" provision), certain uses of copyrighted works that might otherwise be considered an infringement of copyright are permitted. ${ }^{172}$ The fair use doctrine enables courts to balance the interests of copyright owners against the interests of subsequent creators and the public. ${ }^{173}$ It seems that, in many cases, the use of copyrighted works in the context of repair could (and should) be considered fair use. Under the Copyright Act, to determine whether the use made of a work in any particular case is a fair use, a court must consider certain factors, as demonstrated below.

To demonstrate how these factors could be applied in a manner supporting a fair use finding in a repair-related case, let us consider the case of posting repair manuals to an online forum. The first fair use factor is the purpose and character of the use. ${ }^{174}$ Sharing repair manuals serves an important public interest by enabling biomedical technicians to access information they need to keep medical equipment up and running. As discussed in Part II, this is particularly important in times of a pandemic. Such use is also typically not of a commercial nature. Moreover, in some cases, it could be transformative, such as if the upload involves annotation with metadata or similar measures designed to make the information more accessible to the repair community. Yet, even if the use is not transformative, this should not preclude a finding of fair use in these cases. ${ }^{175}$

The second factor is the nature of the copyrighted work.176 Here, the factual nature of the materials, coupled with the fact that they are already published, clearly supports a fair use finding. ${ }^{177}$

Under the third factor, courts consider whether the portion used is "reasonable in relation to the purpose of the copying."178 The use of an entire work can still qualify as fair use when it is reasonably necessary

171 See generally Grinvald \& Tur-Sinai, supra note 12.

17217 U.S.C. $§ 107$.

173 See, e.g., Amanda Levendowski, How Copyright Law Can Fix Artificial Intelligence's Implicit Bias Problem, 93 WASH. L. Rev. 579, 620 (2018).

17417 U.S.C. $\$ 107$.

175 See generally Rebecca Tushnet, Copy This Essay: How Fair Use Doctrine Harms Free Speech and How Copying Serves It, 114 Yale L.J. 535 (2004) (discussing the free speech value of nontransformative copying).

17617 U.S.C. $§ 107$.

177 See Stewart v. Abend, 495 U.S. 207, 237 (1990) (holding that "fair use is more likely to be found in factual works than in fictional works").

178 Authors Guild v. Google, Inc., 804 F.3d 202, 221 (2d Cir. 2015). 
for the purpose. ${ }^{179}$ In the context of repair information, the use of entire manuals (or other informational materials) is generally warranted, to minimize risk of leaving out crucial information or context the technician would need to service the equipment. 180

The fourth factor is the effect of the use upon the potential market for or value of the copyrighted work. 181 Under this factor, courts should only consider "harm cognizable under the Copyright Act."182 Here, OEMs may argue that sharing the information without their permission undercuts their ability to charge for copies of this information. However, repair information is not a work that is created for its own sake, but it is rather incidental to the sale or licensing of medical devices, which should play a role in supporting a fair use finding. ${ }^{183}$ As EFF argued on behalf of iFixit in response to a takedown request,184 "allowing manufacturers a copyright monopoly over repair information risks creating a corollary monopoly on the maintenance of those devices. Far from a legitimate licensing market, that would be a misuse of copyright to inhibit competition in an adjacent market for noncopyrightable goods and services."185 We agree with this analysis.

Based on the foregoing, a fair use finding seems plausible. Surely, each and every particular scenario necessitates independent analysis and weighing of the fair use factors. Indeed, the uncertainty involved in fair use determination is a major shortcoming of this measure, as it only provides cold comfort to potential users of copyrighted works. 186 Nevertheless, as a general matter, we urge courts to apply the fair use analysis in a manner supporting a right to repair, particularly in times of emergency, in the hope that a consistent judicial treatment of such matters would grant an increased level of certainty to potential users. Applying fair use in such a manner is certainly within judicial discretion and with enough cases may also serve as persuasive precedent for adopting a pro-repair interpretation of intellectual property law more broadly.

Another tool that can be operated in a manner that may shift the balance towards greater flexibility for the repair community is patent law's exhaustion doctrine. Repair of a patented product entails a use of

\footnotetext{
179 Levendowski, supra note 173, at 627; EFF Letter, supra note 98.

180 EFF Letter, supra note 98.

18117 U.S.C. $§ 107$.

182 Campbell v. Acuff-Rose Music, 510 U.S. 569, 592 (1994).

183 EFF Letter, supra note 98.

184 See supra notes 96-98 and accompanying text.

185 EFF Letter, supra note 98.

186 Grinvald \& Tur-Sinai, supra note 12 , at 108-11.
} 
the invention, and therefore it counts as patent infringement under Section 271 of the Patent Act unless otherwise permitted.187 Under the doctrine of patent exhaustion, however, an authorized sale of a patented item exhausts the patentee's rights with respect to that item, leaving the purchaser "free to use or resell the product ... without fear of an infringement lawsuit." 188 As part of the "use" of the product, the owner can repair it, though courts have drawn a distinction in this context between repair and reconstruction. While repair is permissible, the reconstruction of a patented product amounts to the making of a new article, and thus, constitutes patent infringement. ${ }^{189}$ Courts have struggled in drawing the line between repair and reconstruction. 190 Recognizing the strong justifications for a right to repair could affect the way courts draw this line towards a classification of more cases as permissible repairs. This could increase the level of certainty for device owners in repairing their devices.

Unfortunately, the exhaustion doctrine cannot provide comfort for hospitals who do not own their devices. Under patent exhaustion jurisprudence, licensing a patented product (in contrast to its sale) does not trigger exhaustion. ${ }^{191}$ OEMs could thus try hiding the true economic nature of a transaction and disguise it as a mere license to evade exhaustion. To minimize this risk, courts must develop clear tests to distinguish between de facto sales from other transactions that are genuinely not sales. ${ }^{192}$

One other limitation of the exhaustion doctrine is the potential that a patent owner can decide to enforce contractual restrictions against the owner or lessee of a device, even amidst exhaustion. In its landmark decision in Impression Products v. Lexmark International, Inc., the Supreme Court held that an authorized sale of a patented item exhausts all patent rights with respect to that item, regardless of any restrictions on use the patentee purports to impose, so that violations of such

\footnotetext{
18735 U.S.C. $§ 271$.

188 See, e.g., Impression Prods. v. Lexmark Int'l, Inc., 137 S. Ct. 1523, 1529 (2017); Quanta Comput., Inc. v. LG Elecs., Inc., 553 U.S. 617, 625 (2008); Bowman v. Monsanto Co., 569 U.S. 278, 283 (2013).

189 See Aro Mfg. Co. v. Convertible Top Replacement, 365 U.S. 336, 346 (1961).

190 See Mallinckrodt, Inc. v. Medipart, Inc., 976 F.2d 700, 709 (Fed. Cir. 1992) ("Although the rule is straightforward[,] its implementation is less so, for it is not always clear where the boundary lies: how much 'repair' is fair before the device is deemed reconstructed."); Mark D. Janis, A Tale of the Apocryphal Axe: Repair, Reconstruction, and the Implied License in Intellectual Property Law, 58 MD. L. REv. 423, 425 (1999) ("The repair-reconstruction dichotomy has baffled and annoyed courts for decades, often driving courts to employ 'loose language."').

191 Impression, 137 S. Ct. at 1534.

192 Grinvald \& Tur-Sinai, supra note 12 , at 103-04.
} 
restrictions have no remedies in patent law.193 The Supreme Court, however, did not rule out the possibility that the patent owner can enforce post-sale restrictions under contract law in a state court. An action for a breach of contract is surely not as effective or as rewarding as a patent infringement lawsuit. ${ }^{194}$ Still, the possibility of being sued may deter consumers and repair businesses, and thus it is important to find ways to decrease this concern. ${ }^{195}$ A statutory provision-like the one included in the Act that would nullify any contract provision that prohibits or restricts a covered healthcare provider from repairing or maintaining medical devices-would alleviate this concern. ${ }^{196}$ In the absence of such an explicit rule, perhaps certain contract law doctrines, including the public policy exception to contract enforcement and the unconscionability doctrine, could be used to strike down post-sale restrictions on repair. ${ }^{197}$

Returning to intellectual property law, another policy tool that is relevant in dealing with contractual restrictions on repair is the patent misuse doctrine. ${ }^{198}$ This doctrine could be useful when no exhaustion is triggered (e.g., when a transaction is not classified as a sale) and the patent owner attempts enforcing restrictions on repair via patent law. Accepting a patent misuse defense raised in infringement litigation

193 Impression, 137 S. Ct. at 1532-33.

194 To begin with, the contractual route cannot be used against entities with which the patent owner does not have a privity of contract. In addition, the remedies for a breach of contract are generally not as broad as the remedies for patent infringement. Even after the Supreme Court decision in eBay, Inc. v. MercExchange, LLC, 547 U.S. 388 (2006), which made it more difficult for patent plaintiffs to obtain injunctions, injunctions are still a common remedy in patent infringement lawsuits. See, e.g., Megan M. La Belle, Against Settlement of (Some) Patent Cases, 67 VAnd. L. Rev. 375, 402 (2014) ("[E]ven after $e$ Bay, permanent injunctions remain the norm in patent cases when there is a finding of infringement."). In contrast, under contract law, specific performance is deemed an extraordinary remedy, awarded at the court's discretion. See, e.g., Alan Schwartz, The Case for Specific Performance, 89 YALE L.J. 271, 272 (1979). The shift from infringement remedies to contract remedies could also decrease the magnitude of monetary damages available to the plaintiff. Among other things, while contract monetary remedies are limited to expectation damages, in a patent infringement suit, the court may award punitive damages and recovery of attorney's fees as well.

195 A threat of litigation through cease-and-desist letters would likely be enough to deter any individual consumer. See generally Leah Chan Grinvald, Policing Cease-andDesist Letters, 49 U.S.F. L. REv. 409 (2015).

196 See supra note 140 and accompanying text.

197 See Daniel Laster, The Secret Is Out: Patent Law Preempts Mass Market License Terms Barring Reverse Engineering for Interoperability Purposes, 58 BAYLOR L. REV. 621, 693-97 (2006).

198 "Patent misuse can be raised as a defense in patent" litigation when the patentee takes unfair advantage of its patent rights. See Gaia Bernstein, The Rise of the End User in Patent Litigation, 55 B.C. L. REv. 1443, 1467 (2014). 
renders the patent unenforceable. ${ }^{199}$ In light of the strong policy considerations favoring repair, courts should consider viewing such restrictions as constituting patent misuse. 200

Another context where a change in intellectual property policy could assist in carving a "legal space" for independent repair of medical equipment is replacement parts. Courts dealing with the patent exhaustion doctrine have clarified that repair may entail the replacement of spent elements, and yet still be permissible.201 But a challenge arises when the replacement part itself is protected by a utility or design patent. Even though the sale of the product exhausts the rights of the patentee with respect to every patented part embedded in the product, exhaustion does not permit the purchaser to make additional copies of patented items. ${ }^{202}$ Thus, when parts are protected by patents, if they must be replaced in the course of repair, it is only the patent holder who can make and supply them.203 Registration of a patent over a part of a product could thus be used to circumvent the application of the exhaustion doctrine that would otherwise sanction repair of the product. ${ }^{204}$ Unfortunately, this is not a mere theoretical concern. In recent decades, there has been an increase in grants of design patents to original equipment manufacturers for components of

199 See, e.g., id.

200 Grinvald \& Tur-Sinai, supra note 12 , at 103-04.

201 In the leading case of Aro Mfg. Co. v. Convertible Top Replacement, 365 U.S. 336 (1961), the defendant replaced the worn-out fabric of the patentable convertible top on his car, and the Supreme Court classified it as a permissible repair. See also SARNOFF, supra note 154, at 2 ("The ... consumer repair right ... [under the patent exhaustion doctrine] is very broad .... It authorizes ... restoring or rebuilding damaged original parts, as well as by substituting new replacement parts.").

202 See, e.g., Bowman v. Monsanto Co., 569 U.S. 278, 284 (2013) (clarifying that "the doctrine restricts the patentee's rights only as to the 'particular article' sold ... it leaves untouched the patentee's ability to prevent a buyer from making new copies of the patented item.") (citation omitted); see also Julie E. Cohen \& Mark A. Lemley, Patent Scope and Innovation in the Software Industry, 89 CALIF. L. REV. 1, 31 (2001) ("The patentee retains the rights to prevent anyone else, including the buyer, from making, using, or selling additional copies of the patented item."); Amelia Smith Rinehart, Contracting Patents: A Modern Patent Exhaustion Doctrine, 23 HARV. J.L. \& TECH. 484, 535 n.4 (2010) ("Under current law, the patent owner retains his right to exclude purchasers of the articles from making the patented invention anew.").

203 One of the arguments brought up in Automotive Body Parts Assn. v. Ford Glob. Tech., LLC, 930 F.3d 1314 (Fed. Cir. 2019) was that design patents over components of a larger product are exhausted upon the first authorized sale of such a product. The court rejected this argument while refusing to formulate a special exhaustion doctrine in design law that would be different than the one employed in the context of utility patents.

204 See SARNOFF, supra note 154, at 2 ("[P]artial-product and fragment design patents ... effectively override [the exhaustion doctrine] .... by prohibiting refurbishment or new manufacture of parts that would be used to repair the overall products."). 
their products. ${ }^{205}$ Patents are not only granted-they are also successfully asserted in litigation. This practice attracted criticism in connection with motor vehicles, where replacement parts (such as doors, headlights, bumpers, etc.) are often needed to repair a car that was damaged in a collision. ${ }^{206}$ In light of the strong justifications undergirding the right to repair, perhaps it is time to reverse the trend and avoid granting partial-product design patents. ${ }^{207}$ In essence, partial products do not qualify at all as statutory subject matter for design protection. Pursuant to Section 171(a) of the Patent Act, patent protection can only be awarded to a "design for an article of manufacture." 208 Arguably, a component of a larger product, which is not sold to be used by itself, and its only value is for restoring the original appearance of the larger product, should not be considered an

205 See id. (noting the growing practice of granting to and assertion by OEMs of partial-product design patents for repair parts). This practice has risen since 1980, following Application of Zahn, 617 F.2d 261 (C.C.P.A. 1980), where the Court of Customs and Patent Appeals held that even fragments of parts of products can be protected by design patents. See SARNOFF, supra note 154, at 11 (noting the CCPA "revised the common and widespread understanding that design patents were limited to the entire appearance of entire products").

206 See, e.g., SARNOFF, supra note 154, at 4 (noting that the practice of granting and asserting partial product design patents "effectively overrides" the right to repair pursuant to the exhaustion doctrine); Dennis Crouch, Design Patents and Replacement Parts, Patently-O (Mar. 22, 2010), https://patentlyo.com/patent/2010/03/designpatents-and-repair-parts.html (noting that "many automobile body parts are protected through design patent" and "[t]his allows the original manufacturers control over the repair-parts market as well"). Surely, design patents for small parts of larger products were registered and asserted in other industries as well. For examples, see Sarah Burstein, Costly Designs, 77 OHIо ST. L.J. 107, 123 (2016). The growth in registrations of such partial-product exterior design patents has accelerated since 2005. Disturbing Trend: Collision Repair Part Design Patents Granted, QualiTy PARTS CoAL., http:// www.keepautopartsaffordable.org/sites/all/themes/framework/pdf_resouce/design_ patents_on_collision_repair_parts_2017-04.pdf (a graph showing a significant increase in the number of design patents on collision repair parts from 2005 to 2015). In response to this, a bipartisan group of lawmakers reintroduced a bill for the "Promoting Automotive Repair, Trade and Sales Act (the "PARTS Act") of 2017" in Congress. S. 812, 115th Congress (2017); H.R. 1879, 115th Congress (2017). Similar legislation was introduced in the 114th Congress (S. 560 and H.R. 1050). The PARTS Act would create a narrow exception from design patent infringement for collision repair parts for cars. While limiting the possibility of enforcing partial-product design patents against independent suppliers of parts or parties that use them for legitimate repairs, the patent owner could still assert the patent against competitors who incorporate the design into their own cars.

207 See generally SARNOFF, supra note 154, at 5 (arguing that Congress has never authorized such patents).

20835 U.S.C. § $171(\mathrm{a})$. 
"article of manufacture" for purposes of the Act. ${ }^{209}$ Besides that, the design of a partial product is not ornamental, as required by the Act.210

The discussion above does not, by any means, intend to offer an exhaustive list of manners by which intellectual property law could be implemented in a way that accommodates a right to repair.

Aside from intellectual property, another branch of the law that could be invoked in certain circumstances to advance a right to repair is antitrust law. ${ }^{211} \mathrm{~A}$ jury in Texas recently found that GE violated antitrust laws by refusing to allow independent technicians to attend training required by GE as a precondition for accessing essential service materials. ${ }^{212}$ In addition, antitrust law could be invoked in certain cases where OEMs refuse to sell service parts, diagnostics, or tools to potential

209 See SARNOFF, supra note 154, at 5 (noting that Congress has authorized design patents only for the overall appearance of "articles of manufacture" and not for parts of such articles, and explaining that " $[\mathrm{t}]$ his is because ornamental designs for functional products are perceived in their entirety as part of the overall functional products that they help to form"); see also Sarah Burstein, The Patented Design, 83 TEnn. L. Rev. 161, 207-08 (2015) (noting that the patented design should be conceptualized as the design as applied to a particular type of product, while defining product as "something sold by an enterprise to its customers"). While parts could be sold in the marketplace separately from the entire products they comprise, if this is only done when needed to repair the larger product, such parts should not be considered "articles of manufacture."

210 The requirement that a design would be ornamental is stated in 35 U.S.C. §171(a): "Whoever invents any new, original and ornamental design for an article of manufacture may obtain a patent therefor, subject to the conditions and requirements of this title." For a detailed analysis of this argument, see Grinvald \& Tur-Sinai, supra note 12, at 11415.

211 Antitrust law has already been invoked in the past in this context. For an example, in 1956, after being accused of unfair practices that violated antitrust laws, IBM entered into a consent decree with the Department of Justice that required IBM to undertake actions that would allow consumers the ability to repair their own machines, or at least choose who undertakes the repair. See U.S. v. IBM, Civil Action No. $72-344$ (S.D.N.Y., Jan. 25 , 1956), reported in 1956 Trade Cases, http://www.cptech.org/at/ibm/ ibm1956cd.html ("IV.(c) to offer to sell at reasonable and nondiscriminatory prices and terms, to owners of IBM tabulating or electronic data processing machines (whether or not the purchaser receives IBM repair and maintenance service) and to persons engaged in the business of maintaining and repairing such machines and during the period when IBM has such parts and subassemblies available for use in its leased machines, repair and replacement parts and subassemblies for any tabulating machines or electronic data processing machines manufactured by IBM.").

212 See Verdict Form, Red Lion Med. Safety Inc. et al. v. General Elec. Co. et al., 2017 WL 2381829 (E.D. Tex. Apr. 26, 2017) (answers to questions 2.3, 2.4.1-2.17); see also Jay L. Himes \& Jonathan S. Crevier, If It Ain't Working, Fix It - With Competition, Not Monopoly, CPI ANTITRUST CHRON. Aug. 2020, at 7, https://www.labaton.com/hubfs/ IF\%20IT\%20AIN\%E2\%80\%99T\%20WORKING,\%20FIX\%20IT\%20\%E2\%80\%94\%20 WITH\%20COMPETITION\%20-\%20CPI\%20-\%20Himes\%208.2020.pdf (discussing the Red Lion case). 
competitors in the market for repair services. ${ }^{213}$ Similarly, certain contractual restrictions that seek to inhibit competition in repair markets may run afoul of antitrust law as agreements in unlawful restraint of trade. 214

In fact, in 2021, the FTC publicly voiced their intention to greater utilize the antitrust laws and other relevant statutes to combat these repair restrictions.215 This includes bringing investigation or enforcement actions "for repair restrictions [that] may constitute tying arrangements or monopolistic practices-such as refusals to deal, exclusive dealing, or exclusionary design" under the Sherman Act or Section 5 of the Federal Trade Commission Act. ${ }^{216}$ This policy statement came after the Commission released its Nixing the Fix: An FTC Report to Congress on Repair Restrictions in 2021.217 The Commission's report found that manufacturers were often unreasonably restricting repair through a variety of methods, including many of the methods discussed

213 With respect to patented parts, it should be clarified that while patent owners generally have the privilege to determine the extent to which they wish to work their invention, a patentee's refusal to sell or license could nevertheless count as antitrust violation in certain circumstances. See, e.g., Image Tech. Servs., Inc. v. Eastman Kodak, Co., 125 F.3d 1195, 1225 (9th Cir. 1997) (finding that Kodak's refusal to sell replacement parts to independent service organizations constitutes an illegal attempt to monopolize the market for service of Kodak photocopiers). Most importantly, on an earlier round of the litigation, the Supreme Court held that even though an equipment manufacturer lacked significant market power for its equipment, it could have sufficient market power in the secondary market for repair parts to be liable under the antitrust laws for its anticompetitive conduct in the aftermarket. See Eastman Kodak Co. v. Image Tech. Servs., Inc., 112 S. Ct. 2072, 2087 (1992) (reasoning that once customers are committed to the particular brand by having purchased a product, they are "locked in" and no longer had any realistic alternative to turn to for repair parts). But see Data Gen. Corp. v. Grumman Sys. Support, 36 F.3d 1147, 1189 (1st Cir. 1994) (declining to impose antitrust liability on a computer manufacturer for its refusal to license its diagnostic software to thirdparty maintenance providers); CSU, L.L.C. v. Xerox Corp. (In re Indep. Serv. Orgs. Antitrust Litig.), 203 F.3d 1322, 1329 (Fed. Cir. 2000) (rejecting the imposition of antitrust liability on Xerox for refusing to sell patented parts and license patented and copyrighted software to independent service organizers that compete with Xerox in the aftermarket).

214 See Sherman Antitrust Act, 15 U.S.C. $\$ 1$ (2012) ("Every contract ... in restraint of trade or commerce ... is declared to be illegal.").

215 See Fed. Trade Comm'n, Policy Statement of the Federal Trade Commission on Repair Restrictions Imposed by Manufacturers and Sellers, https://www.ftc.gov/system/ files/documents/public_statements/1592330/p194400repairrestrictionspolicystatement.pdf.

216 See id.

217 See Fed. Trade Comm'n, Nixing the Fix: An FTC Report to Congress on Repair RESTRICTIONS (2021), https://www.ftc.gov/system/files/documents/reports/nixing-fixftc-report-congress-repair-restrictions/nixing_the_fix_report_final_5521_630pm508_002.pdf. 
above in this Article. ${ }^{218}$ Although the Commission has not yet taken any actions, the Commission's report and policy statement provide an encouraging sign that repair restrictions will be under greater scrutiny in the coming years.

\section{Potential Criticism}

Finally, it is important to address a few counter-arguments that could be made against this Article's support of the right to repair medical equipment.

The main argument stated by manufacturers in support of their refusal to provide access to service information, tools, and parts is patient safety. ${ }^{219}$ The alleged concern is that expanding access "could result in maintenance and repairs of medical devices being performed by untrained personnel, and that inappropriate replacement parts may be used." 220

Indeed, proper servicing is critical to the ongoing safety and effectiveness of many electronic devices. ${ }^{221}$ But the OEMs' concern regarding maintenance and repair of medical equipment by untrained personnel is unsubstantiated. There have been no reports of unqualified people trying to repair medical equipment. Biomedical technicians serving in healthcare facilities and independent service organizations are highly qualified and trained professionals who are hired from the same pool as manufacturer-certified technicians. ${ }^{222}$ And maintenance and repair of medical equipment are far from incidental to their role-these are, in fact, their main responsibilities. In a recent World Health Organization report devoted to "human resources for medical devices," biomedical engineering technicians/technologists are defined as "[f]ront-line practitioners dedicated to the daily maintenance and repair of medical equipment in hospitals, meeting a specified minimum level of expertise." 223 Aside from this, repair of equipment

\footnotetext{
218 Id. at 17-24.

219 See, e.g., Herring, supra note 54; PIRG REPORT, supra note 36, at 11.

220 Koebler, supra note 7 (internal quotation marks omitted) (quoting a letter from AdvaMed, a lobbying firm, sent to Massachusetts lawmakers considering a right to repair bill).

221 U.S. Food \& DRug Admin., FDA Report on the Quality, SAFety, ANd EFFECTiveness of SERVICING OF MEDICAL DEviCES 4 (2018) [hereinafter FDA REPORT], https://www.fda.gov/ media/113431/download (noting that "poor quality servicing may lead to poor device performance, malfunction, and adverse events").

222 Reynolds \& O'Reilly, supra note 54; see also Scher, supra note 36 (noting that "[g]enerally, a practicing technician has an associate's degree in biomedical technology").

223 World Health Org., Human Resources for Medical Devices, The Role of Biomedical ENGINEERS 11 (2017) ("The difference between a technician and a technologist relates to
} 
used in hospitals and healthcare facilities is highly regulated, and there are various safety standards set forth by the U.S. Food and Drug Administration ("FDA") and other relevant agencies that healthcare providers and technicians must comply with. ${ }^{224}$ No pro-repair advocate proposes to exempt healthcare providers or technicians from compliance with such regulations. ${ }^{225}$

Notably, in 2018, the FDA investigated whether additional regulation of independent repair was appropriate and found that there was no objective evidence justifying the imposition of additional regulatory requirements. ${ }^{226}$ In its "Report on the Quality, Safety, and Effectiveness of Servicing of Medical Devices," the FDA found that " $[t]$ he continued availability of third-party entities to service and repair medical devices is critical to the functioning of the U.S. healthcare system."227 Instead of finding safety issues, such as those that have been suggested by manufacturer lobbyists, or a lower quality of servicing by healthcare establishments or third-party servicers, the FDA's report concluded that many OEMs and third-party entities "provide high quality, safe, and effective servicing of medical devices." 228 The restrictions imposed by OEMs, thus, seem to have no nexus to safety concerns. Some have even suggested that the industry's argument in this regard is disingenuous, ${ }^{229}$ referring to the financial benefits for OEMs ensuing from limiting repair. ${ }^{230}$

Sure enough, to perform their work efficiently and safely, biomedical technicians would sometimes need, on top of their general qualifications, access to brand-specific training and information. But

\footnotetext{
the level and number of years of training. Normally technicians train for two years, technologists for three years, but this can differ per country."). As an example of the way the job of a biomedical technician is described in the job market, see Biomedical Technician Job Description, JовHERo, https://www.jobhero.com/job-description/ examples/medical/biomedical-technician (last visited Oct. 27, 2021) (defining the job as to "service the equipment medical professionals depend upon for patient care, such as ventilators and cardiac monitors").

224 See PIRG REPORT, supra note 36, at 4; FDA Report, supra note 221.

225 See Gault \& Koebler, supra note 154 (quoting the office of Senator Ron Wyden regarding its position on exemptions).

226 FDA REPORT, supra note 221.

227 Id. at i.

228 Id.

229 See Scher, supra note 36 (quoting Olivia Webb, a spokesperson for iFixit).

230 PIRG REPORT, supra note 36, at 3; see also Susan Decker, Broken Ventilators Spark Push to End Limits on Who Can Fix Them, Bloomberg (May 16, 2020), https:// www.bloomberg.com/news/articles/2020-05-16/broken-ventilators-spark-push-toend-limits-on-who-can-fix-them (reporting that "the Defense Department... called the profit margins on maintenance 'astounding' and said the markup for parts could be more than $1000 \%$.").
} 
this is where manufacturers could (and should) cooperate with hospitals and third-party providers rather than making it more difficult for them-by increasing availability of training and sharing relevant information rather than suppressing it. The more support offered by manufacturers, the better the quality and efficiency of servicing could be. Technicians are likely to do their job more effectively if relying on information supplied by the manufacturers rather than wasting time on searching, and relying on, pieces of information that may not be complete or updated. Similarly, if there is a genuine concern that inappropriate replacement parts may be used,231 manufacturers should make sure to offer such parts, on fair and reasonable terms, rather than pursuing the opposite direction. Similarly, if a part is amenable to 3D printing, it would be better if manufacturers supply CAD files to ensure that the printed parts are reliable and compatible with the equipment being serviced.

Concern for cyber safety is another issue that could be raised in opposition to the proposals made in this Article.232 Maintaining effective cybersecurity practices around medical equipment is, indeed, essential. A failure to do so may compromise device functionality and result in risk for patients. To address this concern, however, it does not seem necessary to curtail the right to repair-this may seem to be both over-protective and under-protective. A better approach to mitigate cybersecurity risks-which is also recommended by the FDA-seems to be " $[t]$ he development and application of standards and best practices for all entities engaged in the servicing of medical devices ...." ${ }^{233}$ There is a good reason to believe that collaboration between OEMs and healthcare facilities could contribute to the process of developing such standards. In-house biomedical technicians may also play an important role in mitigating cybersecurity risks by ensuring that the latest security patches and software updates are successfully installed.234 In addition, cooperation between OEMs and other servicers of their devices may yield better assessments of cybersecurity threats. Most importantly, having an effective right to repair does not necessitate compromising on the use of basic measures for mitigating cybersecurity risks, such as instituting user authentication and appropriate controls before

231 See supra note 220 and accompanying text.

232 Manufacturers of consumer technologies have raised similar concerns in their opposition to proposals to enact right-to-repair legislation. See Ewan Spence, Apple Fights to Protect Public from their Dangerous iPhone, Fonbes (May 1, 2019, 6:54 PM), https://www.forbes.com/sites/ewanspence/2019/05/01/apple-iphone-right-torepair-parts-legislation-fight-dangerous-tim-cook/\#3581a4db6980.

233 FDA REPORT, supra note 221 , at 25.

234 Id. 
permitting software or firmware updates. Privileged access to various features of the system could be provided to servicers who need it to perform the necessary diagnostic, maintenance, and repair functions.

An additional argument that OEMs could make against a right to repair has to do with their risk in legal liability. The argument would be that if an injury results from the malfunctioning of a medical device, manufacturers may be held responsible, and thus repairs of devices must be under their exclusive control.235 This argument cannot be dismissed entirely out of hand. Under tort law, manufacturers can indeed be held liable for damages resulting from the malfunctioning of their devices in various circumstances. Even if a manufacturer is ultimately not held responsible for an injury, OEMs could argue that the need to litigate over such matters entails significant costs for them. In addition, when a patient is injured in a case involving a malfunctioning of a medical device, the OEM could suffer reputational harms, regardless of whether or not it is sued and found responsible for such injury.

Yet, in this context too, perhaps OEMs should not be so concerned: if no defect in the product is proven, the manufacturer should not be held liable under tort law. ${ }^{236}$ If the malfunctioning causing the injury is attributed to a defect in the product, the OEM should generally be held liable regardless of who conducts maintenance and repair to the device. As to litigation costs, OEMs carry liability insurance and while their insurance premiums may increase as a result of lawsuits, the insurance companies bear the brunt of the costs.237 Moreover, defending against lawsuits is just part and parcel of the costs of running a successful business, which is why insurance premiums are a tax deductible business expense. ${ }^{238}$ Further, inasmuch as biomedical technicians are highly qualified to engage in maintenance and repair, as the discussion above demonstrates, OEMs should be even less concerned.239 With

235 A related argument has to do with the challenges faced by manufacturers when having to repair equipment that has undergone improper servicing by others. See FDA WORKSHOP, DAY 1, supra note 68, at 35-36 (Peter Weems Testimony, describing that manufacturers' service departments encounter challenges when other entities perform improper servicing).

236 See Restatement (ThiRd) of Torts: Products Liability § 2 (Am. L. Inst. 1998).

237 See Erik J. Martin, Everything You Need to Know About Product Liability Insurance, U.S. CHAMBer of Com. (Apr. 19, 2019), https://www.uschamber.com/co/start/strategy/guide-to-product-liability-insurance (last visited Mar. 12, 2021).

238 See Hartford Insurance, Can You Write Off Business Insurance?, HARTFORD InSURANCE, https://www.thehartford.com/business-insurance/write-off-business-insurance (last visited Mar. 12, 2021).

239 See supra notes 222-230 and accompanying text. 
proper training and access to service materials, tools, and parts-this concern should decrease even further. ${ }^{240}$

Another criticism of this Article's support of a right to repair medical equipment could be that this may result in an economic loss for OEMs, which may in turn adversely affect their incentives to innovate and create new devices. ${ }^{241}$ Maintaining control of the repair market most likely serves the economic interests of OEMs, at least in the short run. Yet, this itself is not a reason to deviate from the default societal norm of fair competition. There is no indication that absent exclusive control over the repair market, the incentives for innovation in the medical devices industry would decline to a sub-optimal level.242

Notably, an OEM who supports and facilitates repairs by its customers may experience a growth in business in the long run, to the extent the ability to service and repair their own devices (or choose whom to retain for this purpose) is an important factor in purchasing decisions of hospitals and healthcare facilities. Manufacturers who act in a more cooperative manner and support their customers' efforts to service and repair their devices may enjoy a better reputation that could ultimately translate into greater revenue opportunities as well.

In addition, as discussed above, opening the possibility of independent repairs may yield more user innovation, from which OEMs could ultimately benefit. In fact, as reported by Eric von Hippel in his study of user innovation, some manufacturers actively offer a platform to support user innovation of value to them. ${ }^{243}$ As an example, consider GE's innovation strategy with respect to its MRI machines. Recognizing the importance of user innovation, GE supplied its expensive machines at a very low price to certain users it regarded as most likely to develop improvements, in exchange for a preferred access to the ensuing

\footnotetext{
240 See supra note 231 and accompanying text.

241 Similar concerns have been expressed by manufacturers of consumer electronics in response to proposals for repair state legislation. For discussion, see Grinvald \& Tur-Sinai, supra note 12, at 125-26.

242 Among other things, the connection between the scope of intellectual property protection and the level of incentives provided by the system is not necessarily linear. See Michal Shur-Ofry, IP and the Lens of Complexity, 54 IDEA 55, 96 (2013) ("The expectations that each increase in the scope of IP will lead to a proportionate increase in the level of innovation; that each limitation of that scope will result in a corresponding decrease in innovation; or that we can promote external socially desired values simply by limiting or calibrating the scope of intellectual property protection-are unrealistic."). Thus, even though some of the proposals we have made may narrow the scope of certain intellectual property rights in limited contexts, this would not necessarily result in a corresponding decrease in incentives to innovate.

243 VON HIPPEL, supra note 43, at 130.
} 
innovations. ${ }^{244}$ Similarly, Technicon Corporation has been reported to organize seminars for innovating users of their medical equipment, which ultimately served as the basis for most of the company's new product improvements. ${ }^{245}$ Therefore, rather than hurting their economic interests, perhaps a model based on a higher degree of cooperation and information sharing between OEMs and their customers could be a winning solution for all involved.

\section{CONCLUSION}

COVID-19 has pushed the United States' health system to its limit. Since the start of the pandemic, there have been numerous reports of restrictions imposed by OEMs on the ability of hospital biomedical technicians to effectively service medical devices as required to keep them up and running. These restrictions have been perceived by many as an unnecessary strain on the ability of our healthcare system to deal with the pandemic, and policy makers have urged OEMs to loosen restrictions and increase cooperation with third-party service providers. Federal legislation addressing the intellectual property aspects of this issue was even proposed, yet did not ultimately pass.

As we have argued both on previous occasions and as part of this Article, the battle for a right to repair is highly justified, for multiple reasons. Whereas the need for a right to repair medical equipment is particularly evident during this challenging period, this Article makes the case for a more general right to repair medical equipment. Carving out a safe legal space for repair would serve important policy considerations during "normal" times and increase the preparedness of our legal system for future emergencies.

Although federal legislation implementing a right to repair would be the most effective solution-particularly where intellectual property rights were amended-there are a number of other solutions that could assist even in the absence of any federal legislation. These include policy levers that judges could interpret and implement in a repair-friendly manner, limiting design patents over replacement parts, and greater use of antitrust laws to advance a right to repair. Finally, although there are several potential counterarguments that OEMs may utilize to forestall pro-repair actions, our analysis demonstrates that none of these arguments can justify OEMs' strategies aimed at maintaining control of repair markets. A right to repair medical equipment is necessary, and if

\footnotetext{
244 Id. (explaining that GE wished to ensure that user innovation was based on their machines as a platform, rather than on competitors' machines).

245 Id. at 136.
} 
it were to be embraced by OEMs, it could even provide them with reputational benefits and lead to a mutually beneficial ecosystem. 